\title{
MEDEX: a general overview
}

\author{
A. Jansa ${ }^{1,}{ }^{*}$, P. Alpert ${ }^{2}$, P. Arbogast ${ }^{3}$, A. Buzzi ${ }^{4}$, B. Ivancan-Picek ${ }^{5}$, V. Kotroni ${ }^{6}$, M. C. Llasat ${ }^{7}$, C. Ramis ${ }^{1}$, E. Richard ${ }^{8}$, \\ R. Romero ${ }^{1}$, and A. Speranza ${ }^{9}$ \\ ${ }^{1}$ University of the Balearic Islands (UIB), Palma, Spain \\ ${ }^{2}$ Tel Aviv University (TAU), Tel Aviv, Israel \\ ${ }^{3}$ Meteo-France, Toulouse, France \\ ${ }^{4}$ Institute of Atmospheric Sciences and Climate (ISAC/CNR), Bologna, Italy \\ ${ }^{5}$ Meteorological and Hydrological Service (DHMZ), Zagreb, Croatia \\ ${ }^{6}$ National Observatory of Athens (NOA), Athens, Greece \\ ${ }^{7}$ University of Barcelona (UB), Barcelona, Spain \\ ${ }^{8}$ Laboratoire d'Aérologie (LA/CNRS and Toulouse University), Toulouse, France \\ ${ }^{9}$ University of Camerino (UNICAM), Camerino, Italy \\ * formerly at: Agencia Estatal de Meteorología (AEMET), Palma, Spain
}

Correspondence to: A. Jansa (agusti.jansa@gmail.com)

Received: 13 December 2013 - Published in Nat. Hazards Earth Syst. Sci. Discuss.: 21 January 2014

Revised: 21 June 2014 - Accepted: 26 June 2014 - Published: 5 August 2014

\begin{abstract}
The general objective of the international MEDiterranean EXperiment (MEDEX) was the better understanding and forecasting of cyclones that produce high impact weather in the Mediterranean. This paper reviews the motivation and foundation of MEDEX, the gestation, history and organisation of the project, as well as the main products and scientific achievements obtained from it. MEDEX obtained the approval of World Meteorological Organisation (WMO) and can be considered as framed within other WMO actions, such as the ALPine EXperiment (ALPEX), the Mediterranean Cyclones Study Project (MCP) and, to a certain extent, THe Observing System Research and Predictability EXperiment (THORPEX) and the HYdrological cycle in Mediterranean EXperiment (HyMeX). Through two phases (2000-2005 and 2006-2010), MEDEX has produced a specific database, with information about cyclones and severe or high impact weather events, several main reports and a specific data targeting system field campaign (DTSMEDEX-2009). The scientific achievements are significant in fields like climatology, dynamical understanding of the physical processes and social impact of cyclones, as well as in aspects related to the location of sensitive zones for individual cases, the climatology of sensitivity zones and the improvement of the forecasts through innovative methods like mesoscale ensemble prediction systems.
\end{abstract}

\section{Introduction}

The MEDiterranean EXperiment (MEDEX) has been an international project oriented to an improved understanding and better forecasting of cyclones that produce high impact weather in the Mediterranean. The basic motivation of MEDEX is that at least part of the Mediterranean cyclones produce high impact weather or at least severe weather, thus potentially generating high impacts on exposed and vulnerable sectors. It is well known that deep and intense cyclones produce severe weather, in particular strong winds and/or heavy precipitations anywhere, not only in the Mediterranean. In the Mediterranean, several examples of intense cyclones associated with severe weather can be cited (Homar et al., 2002b; Hamadache et al., 2003; De Zolt et al., 2006; Genovés et al., 2006; Lagouvardos et al., 1996, 2007, among others). It is almost obvious that severe weather has to accompany explosive cyclones, which are not so rare in the Mediterranean (Kouroutzoglou et al., 2011).

However, severe weather and high impact weather in the Mediterranean are not exclusively associated with intense cyclones. In particular, there are cases of very heavy precipitation (Rivera and Riosalido, 1986; Riosalido et al., 1988; Sénési et al., 1996; Buzzi et al., 1998; Kotroni et al., 1999; Romero et al., 2000; Nuissier et al., 2008) that are not related 
to particularly intense cyclones. In most such cases a large amount of the precipitation appears to be the result of deep moist convection, in particular that produced by mesoscale convective systems (MCS) that may affect the same area for a relatively long time. The complex topography of the Mediterranean area, characterised in many places by steep mountains close to the sea, favours the occurrence of heavy rain and subsequent flash floods. The high population density in the coastal areas, as well as many infrastructures and historical and artistic settlements, make these areas especially vulnerable, easily converting severe weather into socially and economically high impact weather.

When examining in detail the above cases as well as other similar historical events, in many examples there is no evidence of the presence of intense cyclones. Still, weak or moderate cyclones are very often observed in the vicinity of the affected areas, playing a role in the organisation of the heavy precipitating systems. The underlying idea is that the presence of a weak or moderate cyclone is enough to organise a low-level warm and moist inflow towards an area of potential ascending motion and potential convective instability, where the heavy precipitation occurs in response (Jansa, 1997). This inflow contributes to the precipitation feeding, and, being warm and moist, tends to increase the convective instability. The indirect role of a cyclone in determining the occurrence of heavy precipitation has been stated in Jansa et al. (1991, 2000a) or Ramis et al. (1994), among other papers.

From a more systematic point of view, the western Mediterranean basin has been explored, looking for the simultaneity and possible connection between heavy rain and cyclonic presence (Jansa et al., 2001a). The conclusion is that in more than $80 \%$ of heavy rain cases, a cyclone is found in the vicinity of the affected area, in a proper location for organising a warm and moist inflow of air originally located in the marine boundary layer over the Mediterranean (Jansa, 1997; Berto et al., 2004). Most such cyclones exhibit only weak or moderate intensity.

Regarding the eastern Mediterranean, some studies also relate heavy rain to cyclonic presence (see Xoplaki et al., 2000; Kotroni et al., 2005; Ziv et al., 2006; Houssos et al., 2008; Houssos and Bartzokas, 2006; Tolika et al., 2007; Lagouvardos et al., 2007; among others). Especially over Greece, heavy precipitation amounts and/or heavy snowfall can be related to cold surges that are accompanied by the passage of a fast moving cold front from the north towards the south, and gale force winds, especially in the gaps between mountains in northern Greece and over the Aegean Sea. A sharp temperature decrease over the whole country and a sharp pressure rise are also observed. In the framework of these cases, heavy rainfall amounts may exceed $100 \mathrm{~mm}$ in $24 \mathrm{~h}$. The lifetime of these surges is normally from 1 to 3 days, extending up to 10 days in exceptional cases (Lagouvardos et al., 1998).

In other papers (Toreti et al., 2010; Reale and Lionello, 2013), the connection between cyclones and heavy precipitation is considered in general for the whole Mediterranean region (east and west).

In summary, heavy precipitation in the Mediterranean, including heavy snowfall, is in some cases directly related to intense cyclones and in some events indirectly linked to weak or moderate cyclones. In any case, a distinct cyclonic signature is usually found in connection with the onset of this kind of severe weather.

Regarding strong winds, it is clear that in the vicinity of an intense cyclonic centre, large pressure gradients are present and strong winds are generated, but some local disturbances, connected to the complex Mediterranean geography, would also play a key role in the generation and/or intensification of some Mediterranean strong winds, mainly those known as "local winds" (like the Mistral-Tramontane, Bora, Etesian and so on). Many of the local disturbances take the shape of dipolar pressure anomalies (see, for instance, Jansa, 1987, 1997; Campins et al., 1995). On the other hand, although many Mediterranean windstorms can be related to Mediterranean cyclones, some of them are mainly associated with external intense cyclones (Nissen et al., 2010).

Obviously there are many weak or moderate cyclones or shallow depressions in the Mediterranean that do not produce any severe or high impact weather. Still, an investigation of Mediterranean cyclone properties is required to understand their potential role in causing severe weather better. In this sense, the general objective of MEDEX is meaningful, and becomes a significant research topic for the Mediterranean area.

This paper, of which all the co-authors have been members of the MEDEX Science Steering Committee, aims to provide a quick look at what MEDEX has investigated and achieved during its effective time span, namely from 2000 to 2010. The second section provides a succinct history of MEDEX, including aspects of its organisation, and serves to frame this project in the context of the WMO research activities, and also reviews the project organisation. The third section highlights and describes the main products of MEDEX. The fourth section is devoted to some specific scientific results of MEDEX. The paper ends with a brief conclusion.

\section{MEDEX history and organisation}

There is a long history of research devoted to Mediterranean cyclones and their consequences. A review of this history is out of the scope of this paper. We only refer here to some steps that can be considered important in the genesis and development of MEDEX, particularly in the framework of the World Meteorological Organisation (WMO) research on this topic.

First we can refer to the ALPEX project. ALPEX (the ALPine EXperiment) was the last field experiment of the Global Atmospheric Research Programme (GARP), a main scientific programme under the auspices of WMO and 
the International Council of Scientific Unions (ICSU). The ALPEX field phase took place in 1982. ALPEX intended to obtain experimental documentation of the influence that a pronounced but limited in horizontal extension mountainous chain like the Alps exerts on the atmospheric flows. The Alpine region was selected mainly due to the important phenomenon of lee cyclogenesis. Alpine lee cyclogenesis is the most prominent type of Mediterranean cyclogenesis, probably explaining the highest world frequency of cyclones (Pettersen, 1956). Moreover, at that time, forecasting of lee cyclogenesis was a challenging problem, mainly due to the difficulty in adequately representing the effects of orography in numerical models. High interest was also raised about the very important wind systems that are more or less directly related to the Alpine lee cyclogenesis, namely the MistralTramontane wind system and the Adriatic Bora.

Less attention was paid at that time to the heavy rain topic. In general, diabatic/moist processes, which involve scales of motion smaller than those characterising cyclones and cyclogenesis, were the main object of investigation of the MAP field project in 1999 with reference to the Alpine area (see Bougeault et al., 2001).

In the very preliminary volume devoted to ALPEX scientific results (ICSU/WMO, 1982), around half of the contributions were specifically devoted to the Alpine lee cyclogenesis and associated winds. Also, a high percentage of contributions in these topics were presented at the ALPEX Final Conference, in Venice, in 1985 (ICSU/WMO, 1986). Work on ALPEX, and particularly on the Alpine lee cyclogenesis (including theories and analysis of observations) and its consequences, continued for years, and many papers were published until about the mid-nineties.

At the time of the ALPEX conference in Venice, another project on Mediterranean cyclones had started under the auspices of WMO, namely the Mediterranean Cyclones Study Project (MCP), endorsed in the framework of the WMO Programme on Short- and Medium-Range Weather Prediction Research (PSMP), later grouped into the Programme on Weather Prediction Research (PWPR). MCP was proposed during the Sofia Consultation on Mediterranean Cyclones (WMO/PSMP, 1984), held in 1983, in response to a decision by the IX WMO Congress. The object of MCP was the study of Mediterranean cyclones in general. MCP was initially conducted by three activity centres (the meteorological services of Bulgaria, Egypt and Italy); the meteorological service of Spain (AEMET, Instituto Nacional de Meteorologia, INM, at that time) was soon added as the fourth activity centre. MCP lasted from 1983 to 1995 , when PWPR disappeared due to a change in the research organisation within WMO. The project was first headed by N. Godev, and later (from 1991) by D. Radinovic, with A. Jansa and P. Alpert as vice-chairmen. The operating mode included periodic specific meetings, with a wider participation than that of the activity centre members, in which scientific achievements were presented and discussed and subsequently published (WMO/PSMP, 1986, 1987, 1989, 1991; WMO/PWPR, 1994). D. Radinovic produced a startup document in 1987 (Radinovic, 1987). An important task in cyclone compilation was performed by the regional centre of INM in the Balearics (INM, 1992-1995), which in 1994 was declared the Regional Research Centre on Mediterranean Cyclones.

In the time period between MCP and MEDEX, WMO and INM jointly organised an important "Symposium on Cyclones and Hazardous Weather in the Mediterranean", held in Palma de Mallorca in April 1997. The symposium was attended by around 200 people, and 111 contributions were presented (see Bougeault and Jansa, 1997). This symposium can be considered to be the starting point of MEDEX, given that in a parallel meeting, INM (through A. Jansa) was invited to prepare a proposal for a project on Mediterranean cyclones (MEDEX) likely to be integrated into the new research scheme of WMO.

A first draft of MEDEX was submitted in 1998 to the Science Steering Committee (SSC) of the new WMO World Weather Research Programme (WWRP). SSC/WWRP encouraged the development of MEDEX with the help of an interim steering committee (MISC). MISC was formed by eighteen people from several countries, who produced a renewed "MEDEX Preliminary Research Proposal", submitted to SSC/WWRP in 2000 (Jansa et al., 2000b). In that session SSC/WWRP approved MEDEX as a "Research and Development Project (RDP)" within WMO/WWRP. MISC, once reduced in its number of members, became the MEDEX Science Steering Committee (MSSC). It underwent only small variations in composition and number of members during the entire subsequent MEDEX life (see Appendix, Table A1) chaired by A. Jansa.

In 2001, a further developed MEDEX proposal (Jansa et al., 2001b) was presented to the SSC/WWRP, with the indication that it comprised the First Phase of the project, planned until 2005. After the approval of this proposal, the MEDEX First Phase was formally initiated.

During the First Phase, MEDEX was mostly oriented to the improvement of knowledge about the cyclones that produce severe and/or high impact weather in the Mediterranean. Four specific objectives were defined for this phase:

1. to build a dynamical climatology of cyclones;

2. to study the factors involved in their genesis and evolution (including both the physical understanding and numerical simulation of these factors);

3. identification of sensitive areas where more and/or better observational data would produce better forecasts;

4. analysis of the societal impacts and benefits (an objective added when the project was already initiated).

Note that the specific objective 4 included subjects on forecasting verification. 
Table 1. MEDEX meetings and associated scientific presentations $(P=$ number of participants; $M P=$ specific MEDEX presentations).

\begin{tabular}{llccl}
\hline Meeting & Place & $P$ & MP & Other presentations \\
\hline 2001 & Palma (Mallorca, Spain) & 23 & 10 & \\
2002A & Athens (Greece) & 17 & - & \\
2002B & Alcudia (Mallorca, Spain) & 26 & - & Combined with Plinius 4 \\
2003 & Ajaccio (Corsica, France) & 20 & 6 & Combined with Plinius 5 \\
2004 & Barcelona (Spain) & 39 & 19 & \\
Workshop on Social & & & & \\
Impact Research & & & & \\
in MEDEX & & & & \\
2004 A & Barcelona (Spain) & 15 & - & Combined with workshop \\
2004B & Dubrovnik (Croatia) & 23 & 8 & \\
2005A & Madrid (Spain) & 28 & 12 & \\
2005B & Crete (Greece) & 21 & - & Combined with Plinius 7 \\
2007A & Madrid (Spain) & 18 & 5 & \\
2007B & Varenna (Italy) & 10 & - & Combined with Plinius 9 \\
2008 & Nicosia (Cyprus) & 10 & - & Combined with Plinius 10 \\
2009 & Barcelona (Spain) & 21 & - & Combined with Plinius 11 \\
2010 & Corfu (Greece) & 10 & - & Combined with Plinius 12 \\
\hline
\end{tabular}

Sections 3 and 4 inform about products and achievements of this phase, related to the former specific objectives.

Progressive involvement of institutions and individual scientists in MEDEX occurred during the first years of MEDEX operation. The number of participating institutions reached a maximum above thirty, from eighteen different countries. The institutions were mostly national and regional meteorological services, universities and other research organisations. A network of about one-hundred individual scientists was formed, mostly connected with each other through email and a specific MEDEX website. The operating mode included meetings of the MSSC, open to the entire MEDEX community. A summary of the MEDEX meetings (including those held during both the First and Second phases) is presented in Table 1. Many MEDEX meetings were held in combination with Plinius Conferences on Mediterranean Storms (a European Geosciences Union, EGU, initiative). The convergence of objectives between MEDEX and the Plinius conferences produced a positive synergy: the Plinius conferences provided a good forum to the MEDEX community for presenting and discussing the latest scientific results, while the participation of the MEDEX community reinforced the meteorological branch of the Plinius conferences.

With regards to the specific objective 3, it is noteworthy that a Memorandum of Understanding (MoU) was signed in 2003 between the UK Meteorological Office, representing the EUMETNET-EUCOS programme (see http://www. eumetnet.eu/composite-observing-system-eucos), the Spanish INM, representing MEDEX, and the University of the Balearics Islands (UIB). According to this MoU, UIB became the main executor of studies devoted to the identification of sensitive areas, defined as the geographical zones where an improved deployment of observational platforms would improve most significantly our forecasts of cyclones and severe and/or high impact weather in the Mediterranean. EUCOS provided funding to UIB for these specific studies.

About the specific objective 4, a key activity was the organisation of the Workshop on Social Impact Research in MEDEX, held in Barcelona in 2004. The attendance of Roger Pielke Jr. (at that time a member of the SSC/WWRP) was very relevant. It is noteworthy that this workshop promoted the creation of a specific Group of Social Impact Research within MEDEX, led by M. C. Llasat, mainly focused on the creation of a database and the analysis of the societal impacts of heavy rainfalls, floods and windstorms.

During 2005, a working draft for the MEDEX Second Phase was prepared, discussed and informally approved by the MSSC and the MEDEX community (Jansa et al., 2005). The Second Phase of MEDEX was planned for 2006-2010. Five specific objectives were defined for this phase:

1. climatological aspects of cyclones (continuation);

2. physical understanding and numerical simulation of processes (continuation);

3. development and testing of methods related to targeted observations, data assimilation and impact calculation;

4. development and testing of forecasting techniques (EPS, statistical methods, etc.);

5. societal impacts and benefits (continuation).

Note that objectives 1, 2 and 5 express a continuation of the tasks developed in objectives 1, 2 and 4 of the First Phase. Objectives 3 and 4 are different and more application oriented compared to objective 3 of the First Phase. They reveal that the Second Phase of MEDEX was more concerned with 
Table 2. MEDEX databases of cyclones. Four analyses per day.

\begin{tabular}{llllc}
\hline Analysis model & Resolution & Period & Area & $\begin{array}{c}\text { Number of } \\
\text { cyclone } \\
\text { detections }\end{array}$ \\
\hline HIRLAM-INM & $0.5^{\circ} \times 0.5^{\circ}$ lat-lon & 1 Jun 1995 to 31 May 2004 & Western Mediterranean & 15733 \\
ECMWF operational & $0.5^{\circ} \times 0.5^{\circ}$ lat-lon & 1 Jun 1998 to 31 May 2004 & Whole Mediterranean & 19200 \\
ERA-40 & $1.125^{\circ} \times 1.125^{\circ}$ lat-lon & 1 Sep 1957 to 31 Aug 2002 & Whole Mediterranean & 81762 \\
\hline
\end{tabular}

practical questions relating to forecasting improvement than the First Phase.

During the MEDEX Second Phase, and in order to support these more applied tasks, the small MEDEX International Core Steering Committee (MICSC) was established in October 2005, chaired by Jean Pailleux (Meteo-France), while the MSSC continued to take care of scientific tasks.

It is worth mentioning that during its Second Phase, MEDEX was no longer an RDP depending directly on the WWRP. Since it was considered that the aims of MEDEX were to some extent included among the THORPEX objectives, the SSC/WWRP, in its 8th meeting in Kunming, China (October 2005), decided that "the MEDEX representation in WMO will be done through THORPEX rather than directly to the WWRP'. Since then MEDEX activities have been reported to THORPEX or the ICSC.

The planning for the MEDEX Second Phase also considered the implementation of field experiments. Some of these would be "low or moderate" intensity field experiments, while the final one was intended as a "high" intensity experiment. The low-moderate intensity field experiments were accomplished through the participation in the 2008 PREVIEW campaign and through the organisation and execution of the 2009 MEDEX campaign (see below). A high intensity experiment was not finally organised in MEDEX, but we could say that it was virtually "replaced" by the 2012 and 2013 HyMeX SOPs. In fact, the HyMeX Science Plan (Ducrocq et al., 2010) states that "the idea of a multi-scale large field experiment to finalise THORPEX-MEDEX was collected in the MEDEX second phase proposal (2005)". The HyMeX field experiment (Ducrocq et al., 2013) can be considered a materialisation of this idea even though HyMeX is much larger than MEDEX in terms of disciplines and scales. HyMeX is presently an RDP project within WWRP, and includes some of the MEDEX objectives within its wider scope.

In addition to EUMETNET-EUCOS, THORPEX or HyMeX, MEDEX has maintained contacts and collaborations with other international projects. It is worth mentioning the collaboration with the Mediterranean Climate Variability and Predictability project (MedCLIVAR). The Mediterranean cyclones that produce high impact weather, which are the main subject of MEDEX, have been analysed by MedCLIVAR from the climatological point of view. The cooperation with MedCLIVAR was agreed to by P. Lionello with
Table 3. Data in the calendars of severe weather events (MEDEX database).

\begin{tabular}{lrcrr}
\hline Country & $\begin{array}{r}\text { Number of } \\
\text { stations }\end{array}$ & $\begin{array}{c}\text { Period } \\
\text { (yymm) }\end{array}$ & $\begin{array}{r}\text { Number of } \\
\text { events }\end{array}$ & $\begin{array}{r}\text { Number of } \\
\text { data }\end{array}$ \\
\hline Bulgaria & 310 & $9501-0412$ & 203 & 432 \\
Croatia & 44 & $9501-0312$ & 119 & 171 \\
France & 1030 & $9701-0412$ & 468 & 11052 \\
Italy & 113 & $9501-0412$ & 333 & 503 \\
Spain & 5898 & $9501-0412$ & 1012 & 10780 \\
\hline Total & 7395 & & 1577 & 22938 \\
\hline
\end{tabular}

A. Jansa. P. Alpert acted as a link between both projects. Apart from cross-participation in some respective meetings, Lionello et al. (2006) is a tangible result of the MEDEXMedCLIVAR cooperation.

\section{Project results and products}

Apart from purely scientific results (see Sect. 4), MEDEX has produced a variety of tangible products. Regarding the MEDEX First Phase, the main output was the MEDEX database, as well as a comprehensive scientific summary (Buzzi et al., 2005) and a report for EUCOS about sensitivity computations (Jansa et al., 2004), besides a number of reports for the SSC/WWRP and for the MEDEX community. During the Second Phase, the main product was the performance of the MEDEX-2009-DTS campaign, as well as a second report for EUCOS (Jansa and Homar, 2006) about the results of sensitivity computations.

\subsection{MEDEX database}

The MEDEX database was established to support both climatological and physical process studies (specific objectives 1 and 2 of both MEDEX phases). It was constructed in a progressive way and, although it was never totally completed, most of it was ready for use shortly after the beginning of MEDEX.

The MEDEX database (open access, available at http: //medex.aemet.uib.es) contains three blocks of information: a cyclone database, severe weather calendars and a list of selected cases. 
In the cyclone database there are listings and basic information about any kind of cyclone or depression detected in the Mediterranean. There are three lists of cyclones, as obtained from three different series of objective analyses (see Table 2). The technique used for cyclone detection and tracking and for the three-dimensional description of the disturbances can be found in Picornell et al. (2001) and Campins et al. (2006a). Note that in order to avoid excessive noise in the dynamical description of the cyclones, it was decided that the original fields would need to be smoothed; a Cressman filter (Cressman, 1959) with $200 \mathrm{~km}$ of radius was used for that purpose. Correspondingly, all the information that was incorporated into the cyclone database comes from filtered fields. The data for each "detected cyclone" contain almost twenty variables referring to the cyclone as a whole: date, time, code, location, minimum pressure, shift, stability by layers, wind by layers, and almost twenty other variables for every atmospheric layer where the cyclone is still identified (location, minimum geopotential, geostrophic vorticity - in the cyclone centre and average in the whole cyclonic domain -, geostrophic circulation, area, radius - mean and standard deviation -, temperature in the cyclone centre, Laplacian of temperature, temperature gradient - mean and standard deviation -, equivalent temperature gradient - mean and standard deviation -, humidity - mean and standard deviation).

The severe weather calendars are in fact calendars of severe or extreme weather. Only heavy rain and strong wind events are considered. To construct the calendars, the Mediterranean territory was divided into territorial units, which correspond either to natural regions (for Bulgaria) or to administrative or political regions or communities (for Italy, France and Spain); in Croatia, only one territorial unit was considered. An event is defined as a day on which predefined thresholds for precipitation or for maximum sustained wind or gust are exceeded in at least one station of a territorial unit. A datum refers to a single day, territorial unit and station; therefore, several data can be included in the same event if the corresponding threshold was exceeded at different stations of the same territorial unit. The MEDEX community adopted a very simple threshold system for precipitation and wind. The threshold for precipitation is unique for the northern Mediterranean, $60 \mathrm{~mm} \mathrm{day}^{-1}$. Note that the MEDEX calendar does not include data from the southern Mediterranean, which is climatologically drier; that would demand a lower threshold. The precipitation threshold in MEDEX can be considered a continuation of the thresholds used to select events within the former WMO-MCP research project, which were $60 \mathrm{~mm} \mathrm{day}^{-1}$ for Spain, France and Switzerland, and $30 \mathrm{~mm} \mathrm{day}^{-1}$ for Algeria (see INM, 1992-1995). The thresholds for wind do depend on the climatological characteristics of the station or the region. The general thresholds are $18 \mathrm{~m} \mathrm{~s}^{-1}$ for maximum sustained wind (ten-minute average) and $25 \mathrm{~m} \mathrm{~s}^{-1}$ for the maximum daily gust, but for the windiest stations or windiest regions, the thresholds are increased to 25 and $33 \mathrm{~m} \mathrm{~s}^{-1}$, respectively.

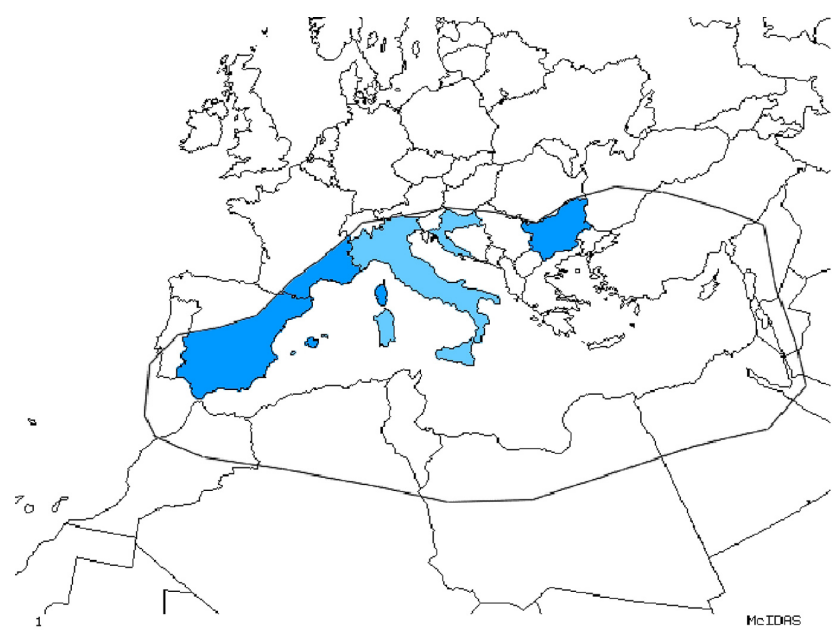

Figure 1. Zones with data in the calendar of high impact weather events included in the MEDEX database. Dark blue corresponds to zones with high density of stations and light blue to zones with low density of stations.

Unfortunately, MEDEX obtained data for only part of the surrounding Mediterranean territories (see Fig. 1). The national meteorological services of Bulgaria, Croatia, France, Italy and Spain and the Catalan Meteorological Service provided these data. Details about data included in the calendars can be seen in Table 3. A significant part of the events include documentation of analysed meteorological fields, direct and derived (from June 1998 to May 2003), and/or satellite pictures (since 2002).

The third part of the MEDEX database is the list of selected cases. The selection of cases was made subjectively by a dozen of the contributing institutions based on a global assessment of the intensity of the phenomena (heavy rain and/or strong wind), the importance of the associated cyclone (if any), as well as the magnitude of the social impact of the event. The period initially considered was 1995-2002, although a few more recent cases were added later. The initial list includes 52 events. Twelve of them were classified as high priority events, thirty as medium priority, and ten as low priority. For every event, information was compiled about the date, the priority level of the case, the affected countries, concise data about heavy rain or strong wind, social impacts, the existence of alerts or warnings, the quality of the model forecasts and formal or informal bibliographical references. In 2003 there were 42 references on the list of selected cases. An outstanding case of the list is the super-storm of 10-11 November 2001 that produced more than 700 casualties in Algeria and some casualties and great damages in the Balearics, where hundreds of thousands of trees were uprooted and where road cuts and telephone and electricity line interruptions occurred (Hamadache et al., 2003; Genoves and Jansa, 2003; see Fig. 2). 
Following the example of MEDEX, various databases of high impact weather events were created later. Papagiannaki et al. (2013) namely recently presented a database that covers all the high impact weather events that occurred over Greece during the period 2001-2011 (201 events in total), while it is updated continuously to provide systematic monitoring and the foundation for future long-term impact analysis.

\subsection{Scientific summary}

By the end of the MEDEX First Phase, Buzzi et al. (2005) had produced a review paper that summarises the scientific progress in the physical and dynamical understanding and numerical modelling of the Mediterranean cyclones and their consequences for weather. The document presents and discusses results of the research performed by members of the MEDEX community under the project scope, mainly with regards to the specific objective 2 of the First Phase, but also includes reviews, ideas and achievements on the same matter obtained previously in parallel actions. Buzzi et al. (2005) is available on the MEDEX website. This valuable document contains 110 references.

\subsection{MEDEX reports for EUCOS}

In connection with objective 3 of the First Phase of MEDEX, and in accomplishment of the EUCOS-MEDEX MoU, two reports were prepared by MEDEX for EUCOS. The first one (Jansa et al., 2004) includes initial studies, made in France and Spain, regarding the sensitivity to the initial conditions (IC) of the prediction of some cases as derived from adjoint models or indirectly through potential vorticity inversion. Other MEDEX studies are also mentioned in this report.

The second report (Jansa and Homar, 2006) pursues a climatology of forecast sensitivities to IC for a subset of cyclones that produced severe and/or high impact weather in the Mediterranean. This subset is composed of the intense cyclones included within the MEDEX database. It was easier to centre the analysis on the population of intense cyclones than on the large variety of severe and/or high impact weather cases related to weak or moderate cyclones, even at the risk of losing many interesting events. Several references about more general climatological studies on Mediterranean cyclones are included in this report.

\subsection{DTS campaigns and MEDEX}

Objective 3 of the MEDEX Second Phase (Jansa et al., 2005) proposes the "development and testing of observational targeting and adaptive strategies (...), oriented to the improvement of the forecasting of the cyclones that produce high impact weather in the Mediterranean", and includes the assessment of the forecasting impact of the eventually added observations. The goal was to apply the data targeting (DT) approach to the prediction of severe and/or high impact weather in the Mediterranean, taking into account that the DT

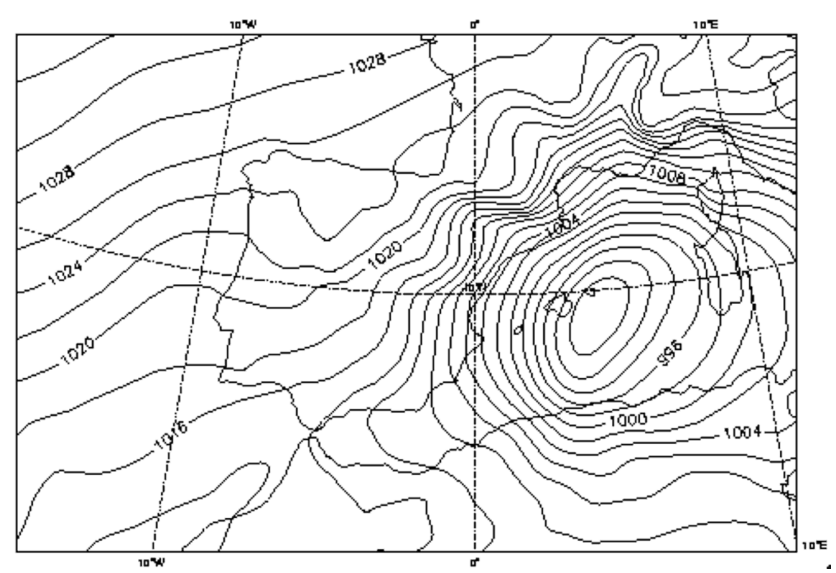

Figure 2. MSP HIRLAM-INM analysis, 11 November 2001 at 06:00 UTC.

approach seeks the identification of sensitive areas where an improvement (in type or number) of the observations is likely to reduce the forecasting error.

This objective was reached through the agreed participation of MEDEX, as a particular voice, during the autumn of 2008 in the Eurorisk-PREVIEW campaign. This project used the data targeting system (DTS) facilities, developed by ECMWF in partnership with the UK Met Office for the campaign (Prates et al., 2009). Several cases of particular Mediterranean interest were selected for targeted observations.

The main action of MEDEX in this line was the specific DTS-MEDEX-2009 campaign (see Jansa et al., 2011). This campaign was sponsored by EUCOS, which also provided organisation and facilities. The ECMWF/UK DTS software developed formerly was used in this campaign. As in Eurorisk-PREVIEW, only operational radiosonde stations and commercial aircraft data (AMDAR) provided additional observations. In addition to AMDAR, DTS-MEDEX-2009 involved 50 radio sounding stations of 16 meteorological services, and 484 extra-soundings were performed. The campaign lasted from 30 September to 20 December 2009. All the additional observations have circulated in the WMO-GTS and are available for observational and assimilation experiments, including impact studies or sensitivity verifications.

The experience accumulated during DTS-MEDEX-2009 has been used fully in the preparation and execution of the SOP1 (Special Observing Period number 1) of HyMeX, the first field phase of this more recent Mediterranean project.

\section{Scientific achievements}

A thorough evaluation of the scientific production in MEDEX is not an easy task, because not all the scientific papers that appeared since the beginning of MEDEX and that were related to the objectives of the project can be considered 
part of the MEDEX production. Part of this work was performed by groups external to MEDEX, and even part of the research developed by members belonging or connected to the MEDEX community may have been done even if MEDEX had not existed, but at the same time some work was motivated by MEDEX and probably would not have been done without MEDEX.

The contributions directly presented to some of the MEDEX meetings (see Table 1) can be considered strict MEDEX production, although preliminary or informal; the same holds for many contributions to the Plinius Conferences on Mediterranean Storms (Table 1), as already mentioned in Sect. 2. Part of both sets of informal scientific contributions later became formal literature. Papers elaborated in this way can be considered MEDEX production, and many of them, according to their relevance, have been included in the following subsections. These subsections also include as MEDEX production other papers that have used MEDEX data explicitly, including the list of selected cases, or that are closely related to the MEDEX objectives and whose authors or co-authors are MEDEX community members.

In order to facilitate a more comprehensive view to the reader, the following sections also mention some papers that are clearly not MEDEX products, but which represent a necessary antecedent of the MEDEX work or serve to frame or complement the MEDEX activities appropriately. As far as possible, MEDEX and non-MEDEX contributions are distinguished in the text.

In the following subsections, the papers that are mentioned, both genuine MEDEX work and connected studies, are grouped according to the specific objectives of the two phases of MEDEX.

\subsection{Climatological aspects}

Before MEDEX and simultaneously with it, although independently of this project, important work has been done concerning the climatology of the Mediterranean cyclones. Prior to describing the climatological work done within MEDEX, it is worth mentioning some of the more relevant non-MEDEX papers. Some pioneering papers were collected in Radinovic (1987). Several others can also be mentioned, like the works done by Berenger (1955, 1960, among others). Still apart from MEDEX, since 1990 we can highlight Alpert et al. (1990a, b), Flocas and Karacostas (1996), Trigo et al. (1999, 2002), Flocas et al. (2001, 2010), Maheras et al. (2001, 2002), and Kouroutzoglou et al. (2011). It is also relevant to mention climatological MedCLIVAR work, partially done in collaboration with MEDEX (see Lionello et al., 2006, and Ulbrich et al., 2012, for a review).

The MEDEX database, in particular the databases of cyclones and the calendars of severe weather, have made possible or at least inspired most of the climatological work done in the framework of MEDEX. Apart from an initial effort devoted to the development of methods for the detection, tracking and description of cyclones, some work has dealt with the analysis of the frequency, distribution and characteristics of Mediterranean cyclones. A preliminary work in this sense is that of Campins et al. (2000), but Picornell et al. (2001) is allegedly the first climatological MEDEX paper in that line. Note that the tracking procedure is based on the Alpert et al. (1990a) method and that some of the ideas about the detection and description of the cyclones are inspired by Radinovic (1997). In Picornell et al. (2001), the analysis method was applied without any filtering. Gil et al. (2003) used analyses from the operational ECMWF model, and compared results on cyclones between the western and eastern Mediterranean, with and without filtering the used fields of departure. Apart from some unpublished work, comparing Mediterranean and Atlantic cyclones, the study by Campins et al. (2006a) represents an important step in this line of research, providing a careful three-dimensional description of western Mediterranean cyclones. The most complete and ambitious paper about the frequency, distribution and description of cyclones for the whole Mediterranean is that of Campins et al. (2011). From all the above papers, several interesting conclusions can be extracted. It can be stressed that some areas are characterised by a high concentration of cyclones, namely Cyprus, Genoa and some secondary zones. Some of these areas are active throughout the year, particularly Genoa, but some tend to present a very marked seasonal behaviour, like the interior of the Iberian Peninsula or Saharan areas, with cyclones occurring almost exclusively during summer (and spring). On the contrary, the Ionian Sea has a minimum of activity during summer. In Cyprus the maximum activity is during summer, but the activity remains important the rest of the year. Partial seasonality can also be found in the Aegean Sea or the Adriatic Sea, with relative maximum activity during winter, or in the maritime zone situated between the southeastern Iberian Peninsula and the African coast, with maximum activity during summer. The seasonality and the genesis location determine the characteristics of the cyclones, such as their thermal structure or their vertical depth. For instance, most of the summer cyclones are warm and shallow depressions, while most of the winter-time disturbances are deep cyclones. Most of the Genoa or Tyrrhenian Sea cyclones are deep lows, while most of the disturbances in Cyprus, Saharan areas, and the interior of the Iberian Peninsula or Algerian Sea are warm and shallow depressions.

Particular aspects like special attention to intense cyclones are considered in other studies (Genovés et al., 2006) or are included in other papers (like Homar et al., 2007). Figure 3 shows the geographical distribution of intense Mediterranean cyclones, defined as having a total geostrophic circulation greater than $7 \times 10^{7} \mathrm{~m}^{2} \mathrm{~s}^{-1}$ (Homar et al., 2007).

An independent effort on this subject was conducted in France, based on the tracking algorithm of cyclones developed by Ayrault and Joly (2000). Some unpublished presentations and summaries have been prepared along this line by 


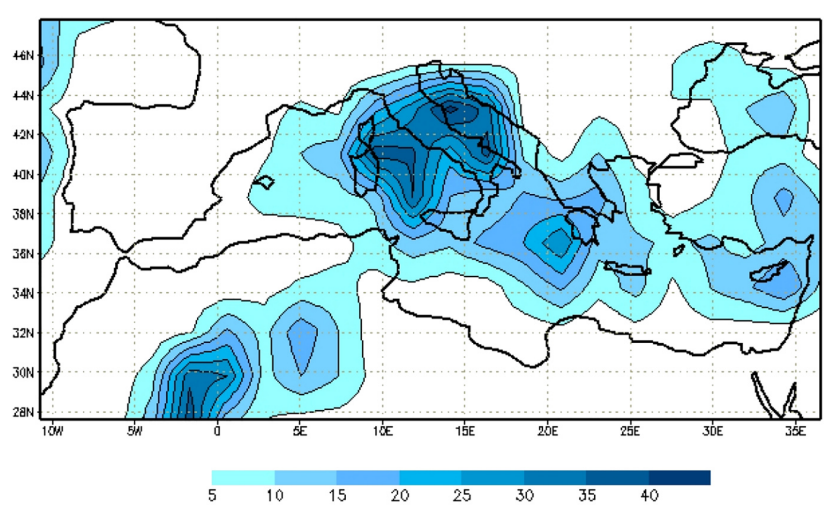

Figure 3. Geographical distribution of intense cyclones; that is, cyclones with a geostrophic circulation larger than $7 \times 10^{7} \mathrm{~m}^{2} \mathrm{~s}^{-1}$ and with a duration of at least $24 \mathrm{~h}$. The isolines refer to the average number of cases per year, in $2.25^{\circ} \times 2.25^{\circ}$ lat-lon squares. The data are based on ECMWF-ERA-40 reanalysis, 1957-2002 (Homar et al., 2007; courtesy of Joan Campins, AEMET; Uppala et al., 2005).

Bruno Joly, Alain Joly and Philippe Arbogast. A recent climatology of cyclones based on the $850 \mathrm{hPa}$ vorticity maximum tracks shares common features with the aforementioned works (see Fig. 4 and Joly and Arbogst, 2010).

In Croatia, operational analyses of the ECMWF were used to evaluate the cyclonic activity over the Adriatic Sea (Horvath et al., 2008). These analyses identified four types of cyclogenesis over the Adriatic. These cyclones produce a chain of weather phenomena on the Adriatic coast, where Jugo winds and mountain-induced precipitation precede strong Bora winds.

In MEDEX, some attention was paid to the question of the time evolution of the frequency and characteristics of the Mediterranean cyclones in connection with climatic change (Guijarro et al., 2006). If the total cyclonic circulation in a region is defined by the sum of the geostrophic circulations associated with all detected cyclonic centres (intense, moderate or weak) during the 45 years of the ERA-40 period, the annual total cyclonic circulation shows a significant decrease in the western Mediterranean, mostly in winter and spring, and an increase in the eastern Mediterranean, mainly due to the summer and autumn growth in the frequency of Cyprus weak (thermal?) lows. The decrease in circulation in the western Mediterranean can mostly be associated with the decline in the frequency of all Genoa gulf cyclones. No significant changes are detected in the frequency of cyclones in the maritime zone situated between the southeastern Iberian Peninsula and the African coast, for instance.

Another group of papers focuses on the link between cyclones and severe weather. A point of departure for the concepts used in some of these papers is Jansa et al. (2001a), while Campins et al. (2006b, 2007) present examples for specific regions. Other approaches to the same idea are

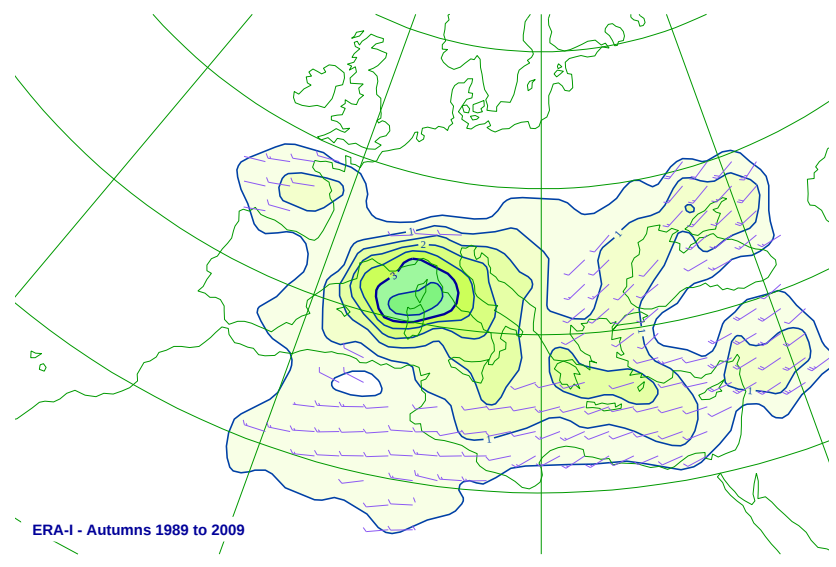

Figure 4. Density of cyclone tracks in autumn. A cyclone location is defined by the $850 \mathrm{hPa}$ vorticity maximum. Only cyclones with a vorticity of at least $1 \times 10^{-4} \mathrm{~s}^{-1}$ are considered. The tracking has been made on $1^{\circ}$ resolution lat-lon grid vorticity fields, using ERA-Interim reanalyses, over the 1989-2009 period. The counting is normalised to periods of two months. The arrows are average displacement velocities (barbs, in knots); only average velocities of at least $10 \mathrm{kt}$ are plotted; in areas with high cyclone track density, the average becomes lower (courtesy of Bruno Joly, Météo-France; Dee et al., 2011).

found in Speranza and Tartaglione (2006) and Tartaglione et al. (2006).

Another way to face the high impact weather from the climatological point of view is the identification, through statistical methods like principal component and cluster analysis, of the atmospheric patterns that are associated with this kind of weather. In Météo-France some unpublished work in this sense was done by Bruno Joly and other researchers. Later, already in the process of transition from MEDEX to HyMeX, the work by Nuissier et al. (2011) can be mentioned. Tartaglione et al. (2009) deal with similar aspects, but with reference to Italy. Analogous research lines were explored in Spain, with papers referring to atmospheric patterns related to heavy rain in the Balearics (Lana et al., 2007) and for the whole Spanish and French Mediterranean area (Martinez et al., 2008). For Bulgaria, the work by Tsonevsky et al. (2010) can be cited.

In general, the work done in MEDEX or in connection with MEDEX confirms the relatively near presence of a cyclonic centre in most of the atmospheric patterns associated with heavy precipitation. The associated cyclones are sometimes weak and/or shallow, that is not necessarily intense and/or vertically deep. The association between strong wind and close cyclone is less frequent. The cyclones associated with strong wind tend to be intense and deep and can be centred relatively far from the strong wind area (even out of the Mediterranean, as Nissen et al. (2010) stated while working independently of MEDEX). From the French group research (see Joly and Arbogast, 2010, as a tentative work), 

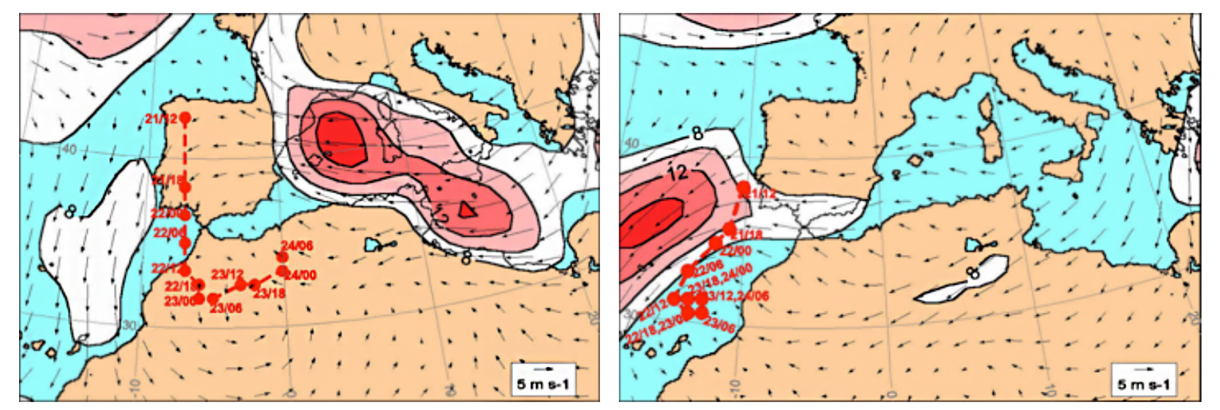

Figure 5. Left panel: position of the cutoff low centre at $300 \mathrm{hPa}$ (circled), from 12:00 UTC to 06:00 UTC (21-24 October 2000), as simulated in the control run. Vector field and shaded contours show the $48 \mathrm{~h}$ averaged wind and wind speed ( $\mathrm{m} \mathrm{s}^{-1}$ ) greater than $8 \mathrm{~m} \mathrm{~s}^{-1}$ at $1000 \mathrm{hPa}$ from 00:00 UTC to 00:00 UTC (22-24 October 2000). Right panel: the same but for the weakened cutoff low experiment (from Homar et al., 2002a).

it can be inferred that the largest impact regarding strong winds is found over specific areas affected by local winds such as the Mistral or Tramontane, rather than being directly tied to strong $850 \mathrm{hPa}$ vorticity centres, as observed for Atlantic mid-latitude cyclones.

\subsection{Dynamical and physical mechanisms - numerical modelling}

A variety of studies have been performed in this field with regard to the cyclones that produce severe weather in the Mediterranean. Many of these can be considered as genuinely belonging to the MEDEX orbit, and some (cited also in this section) were included in the analysis by Buzzi et al. (2005), but before and after 2005 there has also been significant work on the analysis of dynamical and physical mechanisms of Mediterranean cyclones that produce severe weather, and on numerical modelling.

In fact, studies done before 2000 encouraged and inspired some strategies for facing the second specific objective of MEDEX. By applying the factor separation method of Stein and Alpert (1993), an analysis of four different factors in an ALPEX cyclone development, illustrating the significant role of double, triple, and quadruple synergies, was performed by Alpert et al. (1996). Romero et al. (1997) studied quantitatively the influence of the orography and evaporation factors and their synergy on a heavy precipitation case of northeastern Spain, and demonstrated the leading role of the interaction between both factors.

Later, the consideration for other cases of a dynamic variable such as potential vorticity (PV) as another factor in play in the separation method (by applying PV inversion) permitted the isolation of the role of middle to upper tropospheric dynamics on the cyclone formation and on the convective triggering (Tsidulko and Alpert, 2001; Homar et al., 2002a). In Tsidulko and Alpert (2001), PV and orography are the factors considered in an Alpine lee cyclogenesis. Also, Flocas (2000) had used the PV inversion to diagnose cyclogenetic processes. In Homar et al. (2002a), the modification via PV inversion of the initial and boundary conditions of mesoscale numerical simulations, by incorporating slightly smoothed upper-level PV anomalies, allowed the identification of the importance of the high-level disturbance in the development of a quasi-stationary low-level jet (LLJ) that provided a continuous moisture supply towards the Spanish coast. Figure 5 displays the difference between the low-level flow in a simulation nested in the unperturbed ECMWF analyses and the simulation initialised with the inverted fields obtained from the slightly smoothed PV field.

The roles of boundary factors (e.g. orography and sea surface evaporation) and physical factors (e.g. latent heat release in the cloud systems) were found to be even more critical when the heavy precipitation episode on the Spanish Mediterranean coast was governed by shallow and/or smallsize cyclones. For instance, the numerical simulations of two different mesoscale convective systems (MCS) in Romero et al. (2000) showed that the extreme stationarity and efficiency of both systems can be attributed to the leading role of both kinds of factors within a dynamically weak meteorological setting. Also with regards to the prediction of a quasistationary MCS, Davolio et al. (2007) used high-resolution modelling to study the influence of the initial conditions, the assimilation of surface data and the orographic factor.

Romero et al. (2005), Martín et al. (2006) and Argence et al. $(2006,2008,2009)$ studied the influence of uncertainties associated with the location and intensity of the upper-level trough in cases of heavy rain in the western Mediterranean area. Both PV values and the specific shape and position of the disturbance appear to be critical in determining the amount of precipitation, the location of the maximum rainfall, and the strength and position of the responsible low-level cyclones. They also found that too deep disturbances at high levels are not excessively favourable for the development of shallow cyclones and heavy rains, since they greatly reduce the stationarity of the weather pattern.

In Horvath et al. (2006), the roles of orography, surface sensible heat flux and upper level potential vorticity anomaly are isolated using the factor separation method for 
the analysis of an intense cyclone that produced extremely strong Bora winds. This cyclone was generated in the lee of the Atlas Mountains and fully developed over the central Mediterranean. The orography blocking is responsible for the generation of a low-level shallow vortex in the first phase of the lee development, while an upper-level potential vorticity anomaly is the principal ingredient of this event, responsible for a dominant deepening effect in the later stage of lee formation.

Romero (2008) further exploited the capabilities of the PV inversion approach and the factor separation method in a diagnostic system that implements the concepts of "PV thinking" (Hoskins et al., 1985) of cyclones quantitatively. By switching on and off the PV anomalies of interest, the corresponding solutions to the system of equations can be combined algebraically to isolate the magnitude of both the individual and the synergistic effects of the PV anomalies on the spatial pattern of geopotential-height tendency (and vertical motion) around the cyclone. The potential of the method to elucidate the relative importance of physically meaningful $\mathrm{PV}$ anomalies associated with the undulating tropopause, the low-level thermal field and the latent-heat release, was illustrated for a prototypical intense Mediterranean cyclone: the upper-level PV anomalies contributed very significantly during its whole lifecycle; surface thermal anomalies were fundamental during the development period and for the movement of the system during the later stages; the interaction between the two types of anomalies became the dominant effect during the mature stage of the cyclone, and all other contributions, including the individual and synergistic effects of diabatically generated PV, were generally most relevant during the mature phase of the cyclone.

The presence of small thermal lows has proved to be decisive in the development of convection that tends to produce hail in the northeastern Iberian Peninsula in summer. Tudurí et al. (2003) showed, through numerical simulations, that the action of the thermal low that developed around the Ebro Valley is to inflow moist air from the Mediterranean and then to promote severe convection. Sánchez et al. (2003) numerically investigated the same subject, with similar results. Analogously, convergence produced by Mediterranean cyclones over the maritime areas can lead to organised convective developments like squall lines, often linked to severe weather (Ramis et al., 2009). Non-hydrostatic numerical models have proven their ability to reproduce quite accurately the spatial and temporal distribution of convection and the associated strong winds (Cohuet et al., 2011). In this respect, an analysis and model reconstruction of the historical event of a high impact weather cyclone that hit Italy in November 1966 was tackled by Malguzzi et al. (2006), using a full chain of numerical tools, from a global model to a highresolution, convection-permitting non-hydrostatic model.

The relative influence of latent heat release and other diabatic factors on the genesis and intensification of cyclones in the Mediterranean as compared to the baroclinic mechanism has also been analysed through numerical simulations. Note that this influence has been shown to be very important for the rapid development of both synoptic-scale cyclones (Homar et al., 2002b; Genoves and Jansa, 2003) and smaller mesoscale cyclones (diameter of about $300 \mathrm{~km}$ ) known as medicanes or "Mediterranean hurricanes" (Lagouvardos et al., 1999; Homar et al., 2003; Chaboureau et al., 2012). Numerical simulations have also demonstrated how sensible and latent heat surface fluxes become influential in medicane deepening and trajectory (Tous et al., 2013; Davolio et al., 2009). Without direct connection with MEDEX, the processes involved in Mediterranean explosive cyclogenesis have been studied by Kouroutzoglou et al. (2012).

The quantity and variety of works related to the understanding and numerical simulation of the physical processes involved in the Mediterranean cyclogenesis and eventually in the subsequent adverse weather make it difficult to summarise the main scientific results in this field. However, very synthetically, an idea that can be highlighted is that significant cyclogenesis in the Mediterranean only occurs with the concurrence of a large-scale baroclinic or upper-level disturbance, although the geographical factors (orography and the land-sea contrast) redirect the process to some preferential areas. In a certain way, this is a validation of the old idea of considering the Mediterranean cyclogenesis as a secondary cyclogenesis with regard to the oceanic storm tracks. The shape, intensity and exact location of the resulting surface cyclone can be decisive in triggering or locating strong wind and/or heavy rain.

\subsection{Location of sensitive zones and climatology of the sensitivity}

Some initial work within MEDEX identified the most sensitive areas, i.e. where additional observations would produce the most beneficial impact on the forecasts by using adjoint models or by means of IC perturbations based on PV inversion. As a proxy of the heavy rain, these methods used the water vapour content within an atmospheric box (work by P. Lopez, A. Mezdov, B. Joly and P. Arbogastt; partially included in Jansa et al., 2004). After some parallel work with adjoint models (Homar and Stensrud, 2004), sensitivity computations made with the MM5 adjoint model were the first method adopted to face the work agreed to between MEDEX and EUCOS with regards to the systematic identification of sensitive zones for generic cases of Mediterranean severe and/or high impact weather. Owing to the difficulty in identifying proper response functions (that is, specific aspects tracked by the adjoint sensitivities) for a variety of Mediterranean severe and/or high impact weather types associated with cyclones, a proxy was used as a first approach: the study was focused on intense cyclones, the response function being the pressure around the central area of the cyclone. These studies are based on the assumption that intense cyclones are almost always associated with severe and/or high impact 
weather. In order to manage a large number of cases, the intense cyclones were classified by principal components (PC) and cluster analysis in groups (clusters), and the methodology was applied to the cluster centroid, applying later weight coefficients to construct the total climatology. The starting point for the PC and cluster analysis was the MEDEX project cyclone climatology, particularly the intense cyclone climatology (Jansa and Homar, 2006; Homar et al., 2007).

Other methods for sensitivity computation were tested, such as adjoint methods taking into account analysis uncertainties (called KFS, Doerenbecher and Bergot, 2001), or the method of ensemble sensitivity (Garcies and Homar, 2009, 2010). The ensemble sensitivity was used to construct the climatology of sensitivities for intense Mediterranean cyclone prediction (Garcies and Homar, 2009, 2010).

An indirect approach to the climatology of the sensitivity is through the DTS-MEDEX-2009 campaign (Jansa et al., 2011): the "lead user" had to issue a consensus using the sensitivities computed objectively for the campaign, taking into account the feasibility of additional observations. The distribution of this combined sensitivity defined an approximation to the most sensitive zones for the set of selected cases in the campaign, which not only were intense cyclones, but also heavy rain or strong wind events.

Another aspect that has been studied is the verification of the sensitive information as computed by different methods (adjoint model, ensemble sensitivity or even subjective estimation; Garcies and Homar, 2011).

As a general result, we can confirm that, as expected, the highest sensitivities tend to be located upstream of the main development zones of Mediterranean cyclones, that is many times in the open ocean or inland Africa, where the operational observing network is scarce.

\subsection{Targeted observation and impact of additional observations}

The targeted (or adaptive) observations (for cases of Mediterranean cyclones and/or severe and/or high impact weather in the region) were tested in the Eurorisk-PREVIEW campaign (2008) and in the DTS-MEDEX-2009 campaign, as already mentioned in Sect. 3.4. By using the ECMWF/UK DTS software (Prates et al., 2009), the most sensitive zones, where additional observations had to be deployed, were identified by means of several methods, mostly the ECMWF singular vector method, with the help of other methods and the subjective modulation (see Jansa et al., 2011).

Concerning targeting observations, the main scientific objective was rather to verify the correctness and usefulness of the sensitivity computations and the additional deployed observations.

A way to verify the derived sensitivity information is the introduction of artificial perturbations in the estimated most sensitive zones and to study their evolution throughout the numerical prediction (Garcies and Homar, 2014).
Another way is to analyse the direct impact on the forecast of the additional observations or even of the additional assimilation of some available and unused data, like high-density satellite data (Campins et al., 2013). The results obtained until now are not conclusive, but indicate the partial usefulness of some additional data. It should be stressed that the impact of the targeted observations was here found to be not negligible with respect to the first experiment of that kind called TREC2003 (for Thorpex Regional Campaign; Fourrie et al., 2006).

\subsection{Forecasting methods: testing ensemble prediction systems (EPS)}

It is now recognised by many meteorological services that the application of high-resolution ensemble prediction systems (EPS) is valuable in the framework of severe and/or high impact weather forecast, even on a small scale (Bouttier et al., 2012).

In parallel to MEDEX, several institutions have been working on EPS or statistical forecasting methods. The multimodel-multiboundary ensemble system developed at AEMET (AEMET-SREPS, García-Moya et al., 2011) has been presented to the MEDEX community (in different MEDEX meetings) and discussed. AEMET-SREPS has been tested in cases of Mediterranean severe and/or high impact weather (Callado et al., 2011).

More specifically connected to MEDEX is the work done on EPS at the University of the Balearic Islands. They took practical advantage of the body of knowledge acquired during the course of the project with regards to the roles of dynamical and physical factors in Mediterranean cyclones and heavy rain by designing and testing for MEDEX events three different short-range EPS (Vich et al., 2011a, b): a multiphysics EPS that uses different sets of model physical parameterisations; an ensemble based on perturbing the threedimensional PV features of the input analyses that exhibit intense values and gradients (PV gradient); and an analogous system whose perturbation zones are guided by the model adjoint-derived sensitivity zones (PV adjoint). A thorough verification of the results showed that even though all EPS are skilful and advantageous over a deterministic approach, both PV-perturbed systems beat a multiphysics approach, the PV gradient being the best. Vich et al. (2012) introduced a novel concept consisting of building the ensemble members with the previous approach plus subjectively defined perturbations, drawn by a forecaster or an expert.

It was also shown that the hydrological responses of medium-size catchments tend to filter to a certain extent the meteorological errors (Amengual et al., 2007), while these errors - and thus the value of an ensemble approach - may become critical in small basins (Amengual et al., 2008). 


\subsection{Social impact studies}

Although most of the papers about case studies usually introduce briefly the main impacts produced by the respective event, the Societal Impact Research (SIR) group of MEDEX focused its work (presented every year since its birth in the Plinius conferences) along three main research lines. The first one was the compilation of socio-economic data on impacts produced by the events included in the database already mentioned in Sect. 4.1, and the completion of it for the period 1990-2006. As a result of this work and in collaboration with the European FLASH project, Llasat et al. (2010) published a preliminary cartography and temporal analysis of flood events that have affected the Mediterranean countries. The fruit of this initiative has been the FLOODHYMEX database (Llasat et al., 2013); attending that, the SIR group was followed by the Working Group on Societal Impacts (WG5) of the HYMEX project. Based on the experience gained and following the pioneering initiatives of MEDEX, a database (that is continuously updated) containing all the major events with important socio-economic impacts that occurred since 2000 in Greece has been constructed recently (Papagiannaki et al., 2013).

The second research line was centred on the analysis of requests received by meteorological services as a consequence of the impacts of heavy rains and windstorms, and was developed in collaboration with the regional centre of AEMET in the Balearic Islands and the Meteorological Service of Catalonia (Amaro et al., 2010). The idea, followed by other communications presented at different Plinius conferences, was to take advantage of the hard work developed regularly by meteorological services, as sources of data serve as indicators of societal impact.

In the third one, Llasat et al. (2008) introduced the influence of the changing vulnerability and the perception of population into the evaluation of the high impact weather risk as well as into the observed trends. This task was systematically improved with the creation of a database containing press news relating to floods, heavy rainfalls and severe weather that was published in a newspaper during the period 19822007 (Llasat et al., 2009).

MEDEX has been the birthplace of the current group of $\mathrm{HyMeX}$ dedicated to the analysis of the social impact caused by meteorological and hydrometeorological hazards. It was one of the first bets for interdisciplinary work between the social sciences and the natural sciences for assessing impacts.

Finally, we can mention some MEDEX research on forecast verification, which is a horizontal topic, with connections to the social impact research and to the research on forecast methods and numerical modelling. A particular objective in this sense was the development of a tool to measure the quality of the cyclone forecast (Picornell et al., 2003, 2011).

\section{Conclusions}

This paper has reviewed the main results of the MEDEX international project. These results can be grouped into two categories: the tangible products and the scientific findings.

The tangible products comprise (i) the MEDEX database, with a rich and useful content about cyclones and severe weather in the Mediterranean, (ii) three main written reports, on scientific achievements during the First Phase of MEDEX, on sensitivity computations and on sensitivity climatology, and (iii) the stored sensitivity computations and the additional observations obtained during the DTS-MEDEX-2009 campaign and in association with the Eurorisk-PREVIEW campaign (2008). Additionally, the reports on the project submitted to WMO (SSC/WWRP or ICSC/THORPEX) can also be considered to be tangible MEDEX products.

With regards to scientific achievements, plentiful literature has emerged from MEDEX, concerning several aspects, in particular: (i) climatological aspects (like the characterisation of Mediterranean cyclones, atmospheric patterns associated with severe and/or high impact weather, or the relationship between cyclones and severe and/or high impact weather), (ii) aspects related to the knowledge about the processes involved in the formation and evolution of the cyclones that produce severe and/or high impact weather and in the high impact weather itself (with regards to the factors involved, including dynamical and diabatic forcing, or numerical modelling capabilities), and (iii) the location of high sensitivity areas for the prediction of cyclones that produce severe and/or high impact weather, as well as the climatology of these sensitivities, have been the objects of another series of papers. Some others are relative to the verification of the sensitivity and to the impact of additional observations in the forecasting. (iv) There is also the MEDEX literature on prediction methods, particularly about the use or the improvement of ensemble prediction systems. (v) Finally, a group of MEDEX papers deals with the social impact of the Mediterranean cyclones and associated weather, and with the forecasting verification. Some particularly significant scientific results have been highlighted on each of these aspects in the corresponding subsection under Sect. 4.

The documents associated with MEDEX meetings (such as presentations or minutes) can also be considered to be MEDEX products. In this sense, the Workshop on Social Impact Research in MEDEX (Barcelona, 2004) was an outstanding event, with interdisciplinary contributions coming from different kinds of individuals and organisations. Nineteen papers were presented there.

MEDEX has also contributed to Mediterranean meteorology by keeping alive during a decade the research spirit on the topic in the region, with particular attention to the Mediterranean cyclones and the associated severe and/or high impact weather. 


\section{Appendix A}

Table A1. Members of the MEDEX Science Steering Committee (at least part of the time during the MEDEX life).

\begin{tabular}{ll}
\hline Pinhas Alpert & Israel \\
Philippe Arbogast & France \\
Andrea Buzzi & Italy \\
James Doyle & USA \\
Klaus Hoinka & Germany \\
Branka Invancan-Picek & Croatia \\
Agusti Jansa (chairman) & Spain \\
Vassiliki Kotroni & Greece \\
Maria Carmen Llasat & Spain \\
Abdalah Mokssit & Morocco \\
Jean Pailleux & France \\
Climent Ramis & Spain \\
Romualdo Romero & Spain \\
Evelyne Richard & France \\
Antonio Speranza & Italy \\
\hline
\end{tabular}


Acknowledgements. Many institutions have contributed to the MEDEX accomplishment by giving support, funding activities or providing data and human resources. Some of the most significant institutions are in some way represented by the authors of this paper. Special mention has to be made of AEMET, which, together with the University of the Balearic Islands, has constructed and maintained the MEDEX database. The work associated with this activity has mostly been undertaken by Ana Genovés, Joan Campins and Maria Angeles Picornell (AEMET), all of them authors or coauthors of scientific MEDEX literature and very active participants in the MEDEX campaigns.

The organisational, technical and financial support given by EUMETNET-EUCOS to MEDEX has been very important, particularly for sensitivity studies and for running the MEDEX campaigns. From the management of EUCOS, James Caughey, Bruce Scott and Stefan Klink have provided special help to MEDEX. Most of the work on sensitivity studies has been undertaken or directed by Victor Homar, from the University of the Balearic Islands. Victor Homar has also contributed to this paper through a collaborative reading and improvement of the manuscript.

Jean Pailleux (Météo-France) provided a very effective push for the second phase of MEDEX.

Support, encouragement and guidance have been received from WMO, both from the Secretary (Dr. Du, Dr. Lei) and from the members of the SSC/WWRP.

Some of the participant institutions, not represented by the authors of this paper, have been especially constant and effective in their support to MEDEX. The meteorological services of Catalonia (Montse Aran), Italy (Alessandro Fuccello and Teodoro La Rocca) and Bulgaria (Christo Georgiev) are particularly acknowledged in this respect.

The authors are also very grateful to Piero Lionello (referee), to an anonymous referee and to Uwe Ulbrich (editor) for the corrections and suggestions they formulated during the review of our manuscript. Their contributions have substantially improved the paper.

Edited by: U. Ulbrich

Reviewed by: P. Lionello and another anonymous referee

\section{References}

Alpert, P., Neeman, B. U., and Shay-El, Y.: Climatological analysis of Mediterranean cyclones using ECMWF data, Tellus A, 42, 6577, 1990a.

Alpert, P., Neeman, B. U., and Shay-El, Y.: Intermonthly Variability of Cyclone Tracks in the Mediterranean, J. Climate, 3, 14741478, $1990 \mathrm{~b}$.

Alpert, P., Tzidulko, M., Krichak, S., and Stein, U.: A multi-stage evolution of an ALPEX cyclone, Tellus A, 48, 209-220, 1996.

Amaro, J., Gayà, M., Aran, M., and Llasat, M. C.: Preliminary results of the Social Impact Research Group of MEDEX: the request database (2000-2002) of two Meteorological Services, Nat. Hazards Earth Syst. Sci., 10, 2643-2652, doi:10.5194/nhess-10-2643-2010, 2010.

Amengual, A., Romero, R., Gómez, M., Martín, A., and Alonso, S.: A hydro-meteorological modeling study of a flash flood event over Catalonia, Spain, J. Hydrometeorol., 8, 282-303, 2007.
Amengual, A., Romero, R., and Alonso, S.: Hydrometeorological ensemble simulations of flood events over a small-size basin of Majorca Island, Spain, Q. J. Roy. Meteorol. Soc., 134, 12211242, 2008.

Argence, S., Lambert, D., Richard, E., Söhne, N., Chaboureau, J.-P., Crépin, F., and Arbogast, P.: High resolution numerical study of the Algiers 2001 flash flood: sensitivity to the upperlevel potential vorticity anomaly, Adv. Geosci., 7, 251-257, doi:10.5194/adgeo-7-251-2006, 2006.

Argence, S., Lambert, D., Richard, E., Chaboureau, J.-P., and Söhne, N.: Impact of initial condition uncertainties on the predictability of heavy rainfall in the Mediterranean: a case study, Q. J. Roy. Meteorol. Soc., 134, 1775-1788, 2008.

Argence, S., Lambert, D., Richard, E., Pierre Chaboureau, J., Arbogast, P., and Maynard, K.: Improving the numerical prediction of a cyclone in the Mediterranean by local potential vorticity modifications, Q. J. Roy. Meteorol. Soc., 135, 865-879, 2009.

Ayrault, F. and Joly, A.: The genesis of mid-latitude cyclones over the Atlantic ocean: a new climatological perspective, Compt. Rend. Acad. Sci. Paris, Earth Planet. Sc. Lett., 330, 173-178, 2000.

Berenger, M.: Essai d'etudes meteorologiques du Bassin Mediterraneen - Memorial de la Meteorologie Nationale No. 40, Meteorologie Nacional, Paris, 1955.

Berenger, M.: Les types de temps en Mediterranee - METMAR no. 29, Meteorologie Nationale, Paris, 1960.

Berto, A., Buzzi, A., and Zardi, D.: Back-tracking water vapour contributing to precipitation events over Trentino: a case study, Meteorol. Z., 13, 189-200, 2004.

Bougeault, P. and Jansa, A. (Eds.): INM/WMO International Symposium on Cyclones and Hazardous Weather in the Mediterranean, Universitat de les Illes Balears and Ministerio de Medio Ambiente, Palma de Mallorca, 841 pp., 1997.

Bougeault, P., Binder, P., Buzzi, A., Dirks, R., Kuettner, J., Houze, R., Smith, R. B., Steinacker, R., and Volkert, H.: The MAP special observing period, B. Am. Meteorol. Soc., 82, 433-462, 2001.

Bouttier, F., Vie, B., Nuissier, O., and Raynaud, L.: Impact of stochastic physics in a convection-permitting ensemble, Mon. Weather Rev., 140, 3706-3721, doi:10.1175/MWR-D-1200031.1, 2012.

Buzzi, A., Tartaglione, N., and Malguzzi, P.: Numerical simulations of the 1994 Piedmont Flood: role of orography and moist processes, Mon. Weather Rev., 126, 2369-2383, 1998.

Buzzi, A., Richard, E., and Romero, R.: Summary Report on MEDEX Studies and Scientific Results on Mediterranean Cyclones Causing High Impact Weather, available at: http://medex. aemet.uib.es (last access: 2013), 2005.

Callado, A., Santos, C., Escribà, P., Santos-Muñoz, D., Simarro, J., and García-Moya, J. A.: Performance of multi-model AEMETSREPS precipitation probabilistic forecasts over Mediterranean area, Adv. Geosci., 26, 133-138, doi:10.5194/adgeo-26-1332011, 2011.

Campins, J., Jansà, A., Benech, B., Koffi, E., and Bessemoulin, P.: PYREX Observation and Model Diagnosis of the Tramontane Wind, Meteorol. Atmos. Phys., 56, 209-228, 1995.

Campins, J., Genoves, A., Jansa, A., Guijarro, J. A., and Ramis, C.: A catalogue and a classification of surface cyclones for the western Mediterranean, Int. J. Climatol., 20, 969-984, 2000. 
Campins, J., Jansa, A., and Genoves, A.: Three-dimensional structure of Western Mediterranean cyclones, Int. J. Climatol., 26, 323-343, 2006a.

Campins, J., Jansà, A., and Genovés, A.: Heavy rain and strong wind events and cyclones in the Balearics, Adv. Geosci., 7, 7377, doi:10.5194/adgeo-7-73-2006, 2006 b.

Campins, J., Aran, M., Genovés, A., and Jansà, A.: High impact weather and cyclones simultaneity in Catalonia, Adv. Geosci., 12, 115-120, doi:10.5194/adgeo-12-115-2007, 2007.

Campins, J., Genoves, A., Picornell, M. A., and Jansa, A.: Climatology of Mediterranean cyclones using the ERA-40 dataset, Int. J. Climatol., 31, 1596-1614, 2011.

Campins, J., Navascués, B., Santos, C., and Amo-Baladrón, A.: Influence of targeted observations on short-term forecasts of high-impact weather events in the Mediterranean, Nat. Hazards Earth Syst. Sci., 13, 2891-2910, doi:10.5194/nhess-13-28912013, 2013.

Chaboureau, J.-P., Pantillon, F., Lambert, D., Richard, E., and Claud, C.: Tropical transition of a Mediterranean storm by jet crossing, Q. J. Roy. Meteorol. Soc., 138, 596-611, 2012.

Cohuet, J. B., Romero, R., Homar, V., Ducrocq, V., and Ramis, C.: Initiation of a severe thunderstorm over the Mediterranean Sea, Atmos. Res., 100, 603-620, 2011.

Cressman, G.: An operational objective analysis system, Mon. Weather Rev., 87, 367-374, 1959.

Davolio, S., Buzzi, A., and Malguzzi, P.: High resolution simulations of an intense convective precipitation event, Meteorol. Atmos. Phys., 95, 139-154, doi:10.1007/s00703-006-0200$0,2007$.

Davolio, S., Miglietta, M. M., Moscatello, A., Pacifico, F., Buzzi, A., and Rotunno, R.: Numerical forecast and analysis of a tropical-like cyclone in the Ionian Sea, Nat. Hazards Earth Syst. Sci., 9, 551-562, doi:10.5194/nhess-9-551-2009, 2009.

Dee, D. P., Uppala, S. M., Simmons, A. J., Berrisford, P., Poli, P., Kobayashi, S., Andrae, U., Balmaseda, M. A., Balsamo, G., Bauer, P., Bechtold, P., Beljaars, A. C. M., van de Berg, L., Bidlot, J., Bormann, N., Delsol, C., Dragani, R., Fuentes, M., Geer, A. J., Haimberger, L., Healy, S. B., Hersbach, H., Hólm, E. V., Isaksen, L., Kållberg, P., Köhler, M., Matricardi, M., McNally, A. P., Monge-Sanz, B. M., Morcrette, J.-J., Park, B.-K., Peubey, C., de Rosnay, P., Tavolato, C., Thépaut, J.-N., and Vitart, F.: The ERA-Interim reanalysis: configuration and performance of the data assimilation system, Q. J. Roy. Meteorol. Soc., 137, 553597, doi:10.1002/qj.828, 2011.

De Zolt, S., Lionello, P., Nuhu, A., and Tomasin, A.: The disastrous storm of 4 November 1966 on Italy, Nat. Hazards Earth Syst. Sci., 6, 861-879, doi:10.5194/nhess-6-861-2006, 2006.

Doerenbecher, A. and Bergot, T.: Sensitivity to observations applied to FASTEX cases, Nonlin. Processes Geophys., 8, 467481, doi:10.5194/npg-8-467-2001, 2001.

Ducrocq, V., Roussot, O., Béranger, K., Braud, I., Chanzy, A., Delrieu, G., Drobinski, P., Estournel, C., Ivancan-Picek, B., Josey, S., Lagouvardos, K., Lionello, P., Llasat, M. C., Ludwig, W., Lutoff, C., Mariotti, A., Montanari, A., Richard, E., Romero, R., Ruin, I., Somot, S., with the contributions from Amiridis, V., Anagnostou, E., Anav, A., Andersson, A., Anquetin, S., Arbogast, P., Artale, V., Atencia, A., Auclair, F., Austin, G., Avolio, E., Bajic, A., Bakan, S., Baldi, M., Baldini, L., Barthe, C., Barthes, L., Bastin, S., Belamari, S., Bellecci, C., Bennett, A., Berne, A., Betz, H.-D.,
Blanchemanche, P., Blanchet, P., Bock, O., Borga, M., Boudevillain, B., Bouin, M. N., Boukthir, M., Bourras, D., Bousquet, O., Bouvier, C., Bozzano, R., Bresson, E., Briole, P., Brogniez, H., Brown, W., Brunetti, M., Bruno, C., Buzzi, A., Caccia, J.-L., Cacciani, M., Calmanti, S., Calvet, J. C., Campistron, B., Canals, M., Caniaux, G., Carillo, A., Caumont, O., Cava, D., Ceresetti, D., Cerlini, P. B., Chaboureau, J.-P., Champollion, C., Chanut, J., Chazette, P., Chazottes, A., Chronis, T., Cindri, K., Colin, C., Congeduti, F., Coppola, E., Coquillat, S., Corsmeier, U., Craig, G., Creutin, J. D., Creutin, J.-D., Dabas, A., Davolio, S., De Leo, L., Defer, E., Deidda, R., Dell'Aquila, A., Deltel, C., Déqué, M., Dezileau, L., Di Girolamo, P., Di Sarra, A., Dietrich, S., Doerenbecher, A., Doerflinger, E., Dörnbrack, A., Drillet, Y., Drumond, A., Duffourg, F., Durán, A.-M., Durand, P., Durrieu de Madron, X., Ehret, G., Elefante, C., Elizalde, A., Eymard, L., Ezcurra, A., Federico, S., Feldmann, H., Ferrara, R. M., Filippi, J.-B., Flamant, C., Flossmann, A., Fuà, D., Gacic, M., GajicCapka, M., Garayt, B., García-Herrera, R., García-Serrano, J., Garcon, R., Garnier, V., Garreau, P., Garrouste, O., Gaume, E., Gayet, J.-F., Georgis, J.-F., Gimeno, L., Giordani, H., Giorgi, F., Gomes, L., Gomis, D., Gorgucci, E., Gourley, J., Grasso, F., Grbec, B., Grimalt, M., Grisogono, B., Gualdi, S., Hafid, F., Hagen, M., Harzallah, A., Hernández, E., Herrmann, M., Hertig, E., Hoff, H., Höller, H., Homar, V., Horvath, K., Introna, M., IvatekSahdan, S., Jacobeit, J., Jaubert, G., Jericevic, A., Jordà, G., Jourde, H., Kabidi, K., Kalthoff, N., Katsanos, D., Keckhut, P., Keil, C., Kiemle, C., Klaus, V., Klepp, C., Kotroni, V., Kottmeier, C., Koulali Idrissi, A., Kourafalou, V. H., Labatut, L., Lalande, P., Lambert, D., Lang, M., Lanza, L., Larnicol, G., Laroche, P., Lavaysse, C., Le Borgne, P., Lebeaupin Brossier, C., Leblois, E., Legain, D., Lellouche, J.-M., Lemaître, Y., Levizzani, V., Liberti, G.-L., Llasat-Botija, M., Lohou, F., Losada, T., Lothon, M., Lucarini, V., Lucas, M., Lundgren, K., Mahfouf, J.-F., Mallet, C., Mallet, M., Mamouri, R., Marcos, M., Mari, C., Marsaleix, P., Martano, P., Martin, E., Martinelli, N., Marzano, F., Masson, F., Mastrantonio, G., Mastrorilli, M., Matic, F., Maugeri, M., Michaelides, S. C., Miglietta, M., Minnet, P., Mir, F., Mohino, E., Molinié, G., Moreau, E., Morovic, M., Mortier, L., Mugnai, A., Nanni, T., Neppel, L., Nicolaides, K., Nieto, R., Nuissier, O., Orain, F., Ourmières, Y., Panitz, H.-J., Pannekoucke, O., Papadopoulos, A., Papagiannis, A., Papayannis, A., Pappalardo, G., Pashiardis, S., Pasqualoni, L., Patarcic, M., Payraud, I., Pelon, J., Pensieri, S., Perrone, M. R., Petrucci, O., Piani, C., Picco, P., Pinty, J.-P., G. Pisacane, Plagnes, V., Planche, C., Pointin, Y., Polo, I., Portoghese, I., Price, C., Prieur, L., Protat, A., Puig, P., Quintana Segui, P., Raicich, F., Rambaud, J.-P., Rana, G., Rinke, R., Rizi, V., Roberts, G., Rodríguez-Fonseca, B., Romanou, A., Romanou, N., Roquet, H., Rupolo, V., Ruti, P. M., Saenz, J., Saïd, F., Salameh, T., Sannino, G., Santoleri, L., Sauri, D., Savvidou, K., Sayouri, A., Schädler, G., Schiano, E., Schnitter, R., Schroeder, K., Schwarzenböck, A., Seco, A., Sellegri, K., Sempreviva, A. M., Serpetzoglou, E., Sevault, F., Silvani, X., Simonetta, P., Sofianos, S., Solmon, F., Soubeyroux, J. M., Soula, S., Sparnocchia, S., Spinelli, N., Srnec, L., Stanesic, A., Stanelle, T., Stiperski, I., Struglia, M. V., Taillandier, V., Taupier-Letage, I., Teliman Prtenjak, M., Testor, P., Testud, J., Toth, E., Tridon, F., Trigo, I., Trigo, R., Tsaknakis, G., Tselioudis, G., Tsimplis, M., Tudor, M., Uijlenhoet, R., Van Baelen, J., Van Beeck, P., Vervatis, V., Viltard, N., Vincendon, B., Vinet, F., Vitale, D., Vogel, 
B., Vogel, H., Weill, A., Wirth, A., Wobrock, W., Wuang, X., Yair, Y., Yiou, P., and Zaninovic, K.: : HyMeX Science Plan, available at: http://www.hymex.org/ (last access: 2013), 2010.

Ducrocq, V., Braud, I., Davolio, S., Ferretti, R., Flamant, C., Jansa, A., Kalthoff, N., Richard, E., Taupier-Letage, I., Ayral, P.-A., Belamari, S., Berne, A., Borga, M., Boudevillain, B., Bock, O., Boichard, J.-L., Bouin, M.-N., Bousquet, O., Bouvier, C., Chiggiato, J., Cimini, D., Corsmeier, U., Coppola, L., Cocquerez, P., Defer, E., Delanoë, J., Di Girolamo, P., Doerenbecher, A., Drobinski, P., Dufournet, Y., Fourrié, N., Gourley, J. J., Labatut, L., Lambert, D., Le Coz, J., Marzano, F. S., Molinié, G., Montani, A., Nord, G., Nuret, M., Ramage, K., Rison, B., Roussot, O., Said, F., Schwarzenboeck, A., Testor, P., Van Baelen, J., Vincendon, B., Aran, M., and Tamayo, J.: HyMeX-SOP1, the field campaign dedicated to heavy precipitation and flash flooding in the northwestern Mediterranean, B. Am. Meteorol. Soc., doi:10.1175/BAMS-D-12-00244.1, early online release, 2013.

Flocas, H. A.: Diagnostics of Cyclogenesis Over the Aegean Sea Using Potential Vorticity Invesrion, Meteorol. Atmos. Phys., 73, 25-33, 2000.

Flocas, H. A. and Karacostas, T. S.: Cyclogenesis over the Aegean Sea: identifications and synoptic categories, Meteorol. Appl., 3, 53-61, 1996.

Flocas, H. A., Maheras, P., Karacostas, T., Patrikas, I., and Anagnostopoulou, C.: A 40-year climatological study of relative vorticity distribution over the Mediterranean, Int. J. Climatol., 21, 1759-1778, doi:10.1002/joc.705, 2001.

Flocas, H. A., Simmonds, J., Kouroutzoglou, J., Keay, K., Hatzaki, M., Bricolas, V., and Asimakopoulos, D.: On Cyclonic Tracks over the Eastern Mediterranean, J. Climate, 23, 5243-5257, 2010.

Fourrie, N., Marchal, D., Rabier, F., Chapnik, B., and Desroziers, G.: Impact study of the 2003 North Atlantic THORPEX Regional Campaign, Q. J. Roy. Meteorol. Soc., 132, 275-295, doi:10.1256/qj.05.31, 2006.

García-Moya, J. A., Callado, A., Escriba, P., Santos, C., and SantosMuñoz, D.: Predictability of short-range forecasting: a multimodel approach, Tellus A, 63, 550-563, doi:10.1111/j.16000870.2010.00506.x, 2011.

Garcies, L. and Homar, V.: Ensemble sensitivities of the real atmosphere: application to Mediterranean intense cyclones, Tellus A, 61, 394-406, 2009.

Garcies, L. and Homar, V.: An optimized ensemble sensitivity climatology of Mediterranean intense cyclones, Nat. Hazards Earth Syst. Sci., 10, 2441-2450, doi:10.5194/nhess-10-24412010, 2010.

Garcies, L. and Homar, V.: Verification of objective sensitivity climatologies of Mediterranean intense cyclones: test against human judgement, Q. J. Roy. Meteorol. Soc., 137, 1467-1481, doi:10.1002/qj.872, 2011.

Garcies, L. and Homar, V.: Are current sensitivity products suficiently informative in targeting campaigns?, A DTS-MEDEX2009 case study, Q. J. Roy. Meteorol. Soc., 140, 525-538, doi:10.1002/qj.2148, 2014.

Genoves, A. and Jansa, A.: Diabatic processes contribution to the November 2001 storm, in: Proceedings of the 4th EGS Plinius Conference, Mallorca, Spain, October 2002, Universitat de les Illes Balears, Mallorca, Spain, 2003.
Genovés, A., Campins, J., and Jansà, A.: Intense storms in the Mediterranean: a first description from the ERA-40 perspective, Adv. Geosci., 7, 163-168, doi:10.5194/adgeo-7-163-2006, 2006.

Gil, V. E., Genoves, A., Picornell, M. A., and Jansa, A.: Automated Database Of Cyclones from the ECMWF Model: Preliminary Comparison Between West And East Mediterranean Basins, Proceedings of the 4th EGS Plinius Conference, Mallorca, Spain, October 2002, Universitat de les Illes Balears, Mallorca, Spain, 2003.

Guijarro, J. A., Jansà, A., and Campins, J.: Time variability of cyclonic geostrophic circulation in the Mediterranean, Adv. Geosci., 7, 45-49, doi:10.5194/adgeo-7-45-2006, 2006.

Hamadache, B., Terchi, A., and Brachemi, O.: Study of the meteorological situation which affected the west and the center of Algeria in general and Bab-el-Oued in particular on the 10th November 2001, in: Proceedings of the 4th EGS Plinius Conference, Mallorca, Spain, October 2002, Universitat de les Illes Balears, Mallorca, Spain, 2003.

Homar, V. and Stensrud, D. J.: Sensitivities of an intense Mediterranean cyclone: analysis and validation, Q. J. Roy. Meteorol. Soc., 130, 2519-2540, 2004.

Homar, V., Romero, R., Ramis, C., and Alonso, S.: Numerical study of the October 2000 torrential precipitation event over eastern Spain: analysis of the synoptic-scale stationarity, Ann. Geophys., 20, 2047-2066, doi:10.5194/angeo-20-2047-2002, 2002a.

Homar, V., Ramis, C., and Alonso, S.: A deep cyclone of African origin over the Western Mediterranean: diagnosis and numerical simulation, Ann. Geophys., 20, 93-106, doi:10.5194/angeo-2093-2002, 2002b.

Homar, V., Romero, R., Stensrud, J., Ramis, C., and Alonso, S.: Numerical diagnosis of a small, quasi-tropical cyclone over the western Mediterranean: dynamical versus boundary factors, Q. J. Roy. Meteorol. Soc., 129, 1459-1490, 2003.

Homar, V., Jansà, A., Campins, J., Genovés, A., and Ramis, C.: Towards a systematic climatology of sensitivities of Mediterranean high impact weather: a contribution based on intense cyclones, Nat. Hazards Earth Syst. Sci., 7, 445-454, doi:10.5194/nhess-7445-2007, 2007.

Horvath, K., Fita, L., Romero, R., and Ivancan-Picek, B.: A numerical study of the first phase of a deep Mediterranean cyclone: cyclogenesis in the lee of the Atlas Mountains, Meteorol. Z., 15, 133-146, 2006.

Horvath, K., Lin, Y.-L., and Ivancan-Picek, B.: Classification of cyclone tracks over the Apennines and the Adriatic Sea, Mon. Weather Rev., 136, 2210-2227, 2008.

Hoskins, B. J., McIntyre, M. E., and Robertson, A. W.: On the use and significance of isentropic potential vorticity maps, Q. J. Roy. Meteorol. Soc., 111, 877-946, 1985.

Houssos, E. E. and Bartzokas, A.: Extreme precipitation events in NW Greece, Adv. Geosci., 7, 91-96, doi:10.5194/adgeo-7-912006, 2006.

Houssos, E. E., Lolis, C. J., and Bartzokas, A.: Atmospheric circulation patterns associated with extreme precipitation amounts in Greece, Adv. Geosci., 17, 5-11, doi:10.5194/adgeo-17-5-2008, 2008.

ICSU/WMO: ALPEX Preliminary Scientific Results, GARPALPEX No. 7, Geneva, 1982. 
ICSU/WMO: Scientific Results of the Alpine Experiment (ALPEX): Scientific Papers Presented at the Conference, Venice, Italy, 28 October-1 November 1985, WCRP, ICSU/WMO/GARP JSC - GARP Publications Series No. 27, Geneva, 1986.

INM (A. Genoves, coord.): Boletin PEMMOC, Database on Mediterranean Cyclones and Hazardous Weather, available at: AEMET, Delegation in the Balearic Islands, Palma de Mallorca, Spain, 1992-1995.

Jansa, A.: Distribution of the Mistral. A satellite observation, Meteorol. Atmos. Phys., 36, 201-214, 1987.

Jansa, A.: A general view about Mediterranean meteorology: cyclones and hazardous weather, in: INM/WMO International Symposium on Cyclones and Hazardous Weather in the Mediterranean, Universitat de les Illes Balears and Ministerio de Medio Ambiente, Mallorca, Spain, 33-42, 1997.

Jansa, A. and Homar, V.: Climatology of Sensitivities of High Impact weather in the Mediterranean, EUCOS Report, EUCOS Studies Programme, Reading, UK, 2006.

Jansa, A., Garcia-Moya, J. A., and Rodriguez, E.: Numerical experiments on heavy rain and Mediterranean cyclones, WMO/TD No. 420, WMO, Geneva, 37-47, 1991.

Jansa, A., Genoves, A., and Garcia-Moya, J. A.: Western Mediterranean cyclones and heavy rain, Part 1: Numerical experiment concerning the Piedmont flood case, Meteorol. Appl., 7, 323333, 2000a.

Jansa, A., Alpert, P., Arbogast, P., Buzzi, A., and the other members of the MISC: Preliminary Research Proposal to the WWRP: Cyclones That Produce High Impact Weather in the Mediterranean, MEDEX, available at: http://medex.aemet.uib.es (last access: 2013), 2000b.

Jansa, A., Genoves, A., Picornell, M. A., Campins, J., Riosalido, R., and Carretero, O.: Western Mediterranean cyclones and heavy rain, Part 2: Statistical approach, Meteorol. Appl., 8, 43-56, 2001a.

Jansa, A., Alpert, P., Buzzi, A., Arbogast, P., Doyle, J., Hoinka, K. P., Kotroni, V., Ramis, C., Richard, E., and Speranza, A.: Cyclones that Produce High Impact Weather In The Mediterranean, MEDEX (Phase 1), available at: http://medex.aemet.uib.es (last access: 2013), 2001b.

Jansa, A., Romero, R., Homar, V., and Arbogast, P.: MEDEXEUCOS Report 2003, internal document, available at: http:// medex.aemet.uib.es (last access: 2013), 2004.

Jansa, A. with the members of the MSSC and the MEDEX community: MEDEX Second Phase: Design and Implementation Plan, available at: http://medex.aemet.uib.es (last access: 2013), 2005.

Jansa, A., Arbogast, P., Doerenbecher, A., Garcies, L., Genoves, A., Homar, V., Klink, S., Richardson, D., and Sahin, C.: A new approach to sensitivity climatologies: the DTS-MEDEX2009 campaign, Nat. Hazards Earth Syst. Sci., 11, 2381-2390, doi:10.5194/nhess-11-2381-2011, 2011.

Joly, B. and Arbogast, P.: A refined cyclogenesis tracking climatology in the Mediterranean for charactrerisation and predictability perspectives of automnal intense wind events, available at: http://www.hymex.org/public/workshops/4/Presentations/ WED-morning/W1.1_OralHymex.HC.pdf, 4th HyMeX Workshop, 8-10 June 2010, Bologna, Italy, 2010.
Kotroni, V., Lagouvardos, K., Kallos, G., and Ziakopoulos, D.: Severe flooding over central and southern Greece associated with pre-cold frontal orographic lifting, Q. J. Roy. Meteorol. Soc., 125, 967-991, 1999.

Kotroni, V., Lagouvardos, K., Defer, E., Dietrich, S., Porcu, F., Medaglia, C. M., and Demirtas, M.: The Antalya 5 December 2002 storm: observations and model analysis, J. Appl. Meteorol., 45, 576-590, 2005.

Kouroutzoglou, J., Flocas, H. A., Keay, K., Simmonds, I., and Hatzakia, M.: Climatological aspects of explosive cyclones in the Mediterranean, Int. J. Climatol., 31, 1785-1802, doi:10.1002/joc.2203, 2011.

Kouroutzoglou, J., Flocas, H. A., Hatzaki, M., Keay, K., and Simmonds, I.: On the Dynamics of Mediterranean Explosive $\mathrm{Cy}$ clogenesi, in: Advances in Meteorology, Climatology and Atmospheric Physics, Springer Atmospheric Sciences, edited by: Helmis, C. G. and Nastos, P. T., Springer-Verlag, Berlin, Heidelberg, doi:10.1007/978-3-642-29172-2_80, 2012.

Lagouvardos, K., Kotroni, V., Dobricic, S., Nickovic, S., and Kallos, G.: On the storm of 21-22 October 1994 over Greece: observations and model results, J. Geophys. Res., 101, 26217-26226, 1996.

Lagouvardos, K., Kotroni, V., Nickovic, S., Jovic, D., and Kallos, G.: Observations and model simulations of a winter sub-synoptic vortex over the Central Mediterranean, Meteorol. Appl., 6, 371383, 1999.

Lagouvardos, K., Kotroni, V., and Defer, E.: The 21-22 January 2004 explosive cyclogenesis over the Aegean Sea: observations and model analysis, Q. J. Roy. Meteorol. Soc., 133, 15191531, 2007.

Lagouvardos, K., Kotroni, V., and Kallos, G.: An extreme cold surge over the Greek Peninsula, Q. J. Roy. Meteorol. Soc., 124, 2299 2328, 1998.

Lana, A., Campins, J., Genovés, A., and Jansà, A.: Atmospheric patterns for heavy rain events in the Balearic Islands, Adv. Geosci. 12, 27-32, doi:10.5194/adgeo-12-27-2007, 2007.

Lionello, P., Bhend, J., Buzzi, A., Della-Marta, P. M., Krichak, S., Jansa, A., Maheras, P., Sanna, A., Trigo, I. F., and Trigo, R.: Cyclones in the Mediterranean region: climatology and effects on the environment, in: Mediterranean Climate Variability, edited by: Lionello, P., Malanotte-Rizzoli, P., and Boscolo, R., Elsevier, Amsterdam, the Netherlands, 325-372, 2006.

Llasat, M. C., López, L., Barnolas, M., and Llasat-Botija, M.: Flashfloods in Catalonia: the social perception in a context of changing vulnerability, Adv. Geosci., 17, 63-70, doi:10.5194/adgeo17-63-2008, 2008.

Llasat, M. C., Llasat-Botija, M., and López, L.: A press database on natural risks and its application in the study of floods in Northeastern Spain, Nat. Hazards Earth Syst. Sci., 9, 2049-2061, doi:10.5194/nhess-9-2049-2009, 2009.

Llasat, M. C., Llasat-Botija, M., Prat, M. A., Porcú, F., Price, C., Mugnai, A., Lagouvardos, K., Kotroni, V., Katsanos, D., Michaelides, S., Yair, Y., Savvidou, K., and Nicolaides, K.: High-impact floods and flash floods in Mediterranean countries: the FLASH preliminary database, Adv. Geosci., 23, 47-55, doi:10.5194/adgeo-23-47-2010, 2010. 
Llasat, M. C., Llasat-Botija, M., Petrucci, O., Pasqua, A. A., Rosselló, J., Vinet, F., and Boissier, L.: Towards a database on societal impact of Mediterranean floods within the framework of the HYMEX project, Nat. Hazards Earth Syst. Sci., 13, 13371350, doi:10.5194/nhess-13-1337-2013, 2013.

Maheras, P., Flocas, H., Patrikas, I., and Anagnostopoulou, C.: A 40 year objective climatology of surface cyclones in the Mediterranean region: spatial and temporal distribution, Int. J. Climatol., 21, 109-130, doi:10.1002/joc.599, 2001.

Maheras, P., Flocas, H., Anagnostopoulou, C., and Patrikas, I.: On the vertical structure of composite surface cyclones in the Mediterranean region, Theor. Appl. Climatol., 71, 199-217, 2002.

Malguzzi, P., Grossi, G., Buzzi, A., Ranzi, R., and Buizza, R.: The 1966 "century" flood in Italy: a meteorological and hydrological revisitation, J. Geophys. Res., 111, D24106, doi:10.1029/2006JD007111, 2006.

Martín, A., Romero, R., Homar, V., Luque, A., Alonso, S., Rigo, T., and Llasat, M. C.: Sensitivities of a flash flood event over Catalonia: a numerical analysis, Mon. Weather Rev., 135, 651669, 2006

Martinez, C., Campins, J., Jansa, A., and Genoves, A.: Heavy rain events in the Western Mediterranean: an atmospheric pattern classification, Adv. Sci. Res., 2, 61-64, 2008.

Nissen, K. M., Leckebusch, G. C., Pinto, J. G., Renggli, D., U1brich, S., and Ulbrich, U.: Cyclones causing wind storms in the Mediterranean: characteristics, trends and links to largescale patterns, Nat. Hazards Earth Syst. Sci., 10, 1379-1391, doi:10.5194/nhess-10-1379-2010, 2010.

Nuissier, O., Ducrocq, V., Ricard, D., Lebeaupin, C., and Anquetin, S.: A numerical study of three catastrophic precipitating events over southern France, I: Numerical framework and synoptic ingredients, Q. J. Roy. Meteorol. Soc., 134, 111-130, 2008.

Nuissier, O., Joly, B., Joly, A., Ducrocq, V., and Arbogast, P.: A statistical downscaling to identify the large-scale circulation patterns associated with heavy precipitation events over southern France, Q. J. Roy. Meteorol. Soc., 137, 1812-1827, doi:10.1002/qj.866, 2011

Papagiannaki, K., Lagouvardos, K., and Kotroni, V.: A database of high-impact weather events in Greece: a descriptive impact analysis for the period 2001-2011, Nat. Hazards Earth Syst. Sci., 13, 727-736, doi:10.5194/nhess-13-727-2013, 2013.

Petterssen, S.: Weather Analysis and Forecasting, in: Vol. 1, Motion and Motion Systems, McGraw Hill, New York, 428 pp., 1956.

Picornell, M. A., Jansà, A., Genovés, A., and Campins, J.: Automated database of mesocyclones from the HIRLAM (INM)0.5_analyses in the western Mediterranean, Int. J. Climatol., 21, 335-354, 2001.

Picornell, M. A., Carrassi, N. A., and Jansa, A.: A study on the forecast quality of the Mediterranean cyclones, in: Proceedings of the 4th EGS Plinius Conference, Mallorca, Spain, October 2002, Universitat de les Illes Balears, Mallorca, Spain, 2003.

Picornell, M. A., Jansà, A., and Genovés, A.: A tool for assessing the quality of the Mediterranean cyclone forecast: a numerical index, Nat. Hazards Earth Syst. Sci., 11, 1787-1794, doi:10.5194/nhess-11-1787-2011, 2011.

Prates, C., Richardson, D., and Sahin, C.: Final Report of the Preview Observation Data Targeting System (DTS), ECMWF Tech. Memo., ECMWF, Reading, UK, 581 pp., 2009.
Radinovic, D.: Mediterranean cyclones and their influence on the weather and climate, PSPM Report Series No. 24, WMO, Geneva, 1987.

Radinovic, D.: The basic concept of the methodologies of Mediterranean cyclones and adverse weather phenomena studies, in: INM/WMO International Symposium on Cyclones and Hazardous Weather in the Mediterranean, Universitat de les Illes Balears and Ministerio de Medio Ambiente, Mallorca, Spain, 45-53, 1997.

Ramis, C., Llasat, M. C., Genovés, A., and Jansà, A.: The October1987 floods in Catalonia: synoptic and mesoscale mechanisms, Meteorol. Appl., 1, 337-350, 1994.

Ramis, C., Romero, R., and Homar, V.: The severe thunderstorm of 4 October 2007 in Mallorca: an observational study, Nat. Hazards Earth Syst. Sci., 9, 1237-1245, doi:10.5194/nhess-9-1237-2009, 2009.

Reale, M. and Lionello, P.: Synoptic climatology of winter intense precipitation events along the Mediterranean coasts, Nat. Hazards Earth Syst. Sci., 13, 1707-1722, doi:10.5194/nhess-131707-2013, 2013.

Riosalido, R., Rivera, A., and Martin, F.: Development of a mesoscale convective system in the Spanish Mediterranean Area, in: Proc. 7th Meteosat Scientific Users' Meeting, Madrid, 2730 September 1988, EUMETSAT, Darmstadt, 375-378, 1988.

Rivera, A. and Riosalido, R.: Mediterranean convective systems as viewed by Meteosat, a case study, in: Proc. 6th Meteosat Scientific Users Meeting, Amsterdam, 25-27 November 1986, EUMETSAT, Darmstadt, 101-104, 1986.

Romero, R.: A method for quantifying the impacts and interactions of potential vorticity anomalies in extratropical cyclones, Q. J Roy. Meteorol. Soc., 134, 385-402, 2008.

Romero, R., Ramis, C., and Alonso, S.: Numerical simulation of an extreme rainfall event in Catalonia: Role of orography and evaporation from the sea, Q. J. Roy. Meteorol. Soc., 123, 537559, 1997.

Romero, R., Doswell, C. A., and Ramis, C.: Mesoscale numerical study of two cases of longlived quasi-stationary convective system over eastern Spain, Mon. Weather Rev., 128, 3731-3751, 2000.

Romero, R., Martín, A., Homar, V., Alonso, S., and Ramis, C.: Predictability of prototype flash flood events in the Western Mediterranean under uncertainties of the precursor upper-level disturbance: the HYDROPTIMET case studies, Nat. Hazards Earth Syst. Sci., 5, 505-525, doi:10.5194/nhess-5-505-2005, 2005.

Sánchez, J. L., Fernández, M. V., Fernández, J. T., Tudurí, E., and Ramis, C.: Analysis of mesoscale convective systems with hail precipitation, Atmos. Res., 67-68, 573-588, 2003.

Sénési, S., Bougeault, P., Chèze, J. L., Cosentino, P., and Thepenier, R. M.: The Vaison-La-Romaine flash flood: mesoscale analysis and predictability issues, Weather Forecast., 11, 417-442, 1996.

Speranza, A. and Tartaglione, N.: Extreme events in the Mediterranean area: a mixed deterministic statistical approach, Nuovo Cimento, 29C, 81-88, 2006.

Stein, U. and Alpert, P.: Factor separation in numerical simulations, J. Atmos. Sci., 50, 2107-2115, 1993. 
Tartaglione, N., Speranza, A., Dalan, F., Nanni, T., Brunetti, M., and Maugeri, M.: The mobility of Atlantic baric depressions leading to intense precipitation over Italy: a preliminary statistical analysis, Nat. Hazards Earth Syst. Sci., 6, 451-458, doi:10.5194/nhess-6-451-2006, 2006.

Tartaglione, N., Maugeri, M., Dalan, F., Brunetti, M., Nanni, T., and Speranza, A.: Searching for resemblance between large-scale sea level pressure patterns leading to "intense" precipitation events over Italy, Theor. Appl. Climatol., 95, 183-196, 2009.

Tolika, K., Anagnostopoulou, Chr., Maheras, P., and Kutiel, H.: Extreme precipitation related to circulation types for four case studies over the Eastern Mediterranean, Adv. Geosci., 12, 87-93, doi:10.5194/adgeo-12-87-2007, 2007.

Toreti, A., Xoplaki, E., Maraun, D., Kuglitsch, F. G., Wanner, H., and Luterbacher, J.: Characterisation of extreme winter precipitation in Mediterranean coastal sites and associated anomalous atmospheric circulation patterns, Nat. Hazards Earth Syst. Sci., 10, 1037-1050, doi:10.5194/nhess-10-1037-2010, 2010.

Tous, M., Romero, R., and Ramis, C.: Surface heat fluxes influence on medicane trajectories and intensification, Atmos. Res., 123, 400-411, 2013.

Trigo, I., Davies, T., and Bigg, G.: Objective climatology of cyclones in the Mediterranean region, J. Climate, 12, 1685-1696, 1999.

Trigo, I., Bigg, G., and Davies, T.: Climatology of cyclogenesis mechanisms in the Mediterranean, Mon. Weather Rev., 130, 549-569, doi:10.1007/s00382-005-0065-9, 2002.

Tsidulko, M. and Alpert, P.: Synergism of upper-level potential vorticity and mountains in Genoa lee cyclogenesis - a numerical study, Meteorol. Atmos. Phys., 78, 261-285, 2001.

Tsonevsky, I., Campins, J., Genoves, A., and Jansa, A.: Atmospheric patterns for heavy precipitation in Bulgaria, Roman. J. Meteorol., 10, 1-12, 2010.

Tudurí, E., Romero, R., López, L., García, E., Sánchez, J. L., and Ramis, C.: The 14th July 2001 hailstorm in northeastern Spain: diagnosis of the meteorological situation, Atmos. Res., 67-68, 541-558, 2003.

Ulbrich, U., Lionello, P., Belusic, D., Jacobeit, J., Knippertz, P., Kuglitsch, F. G., Leckebusch, C., Lutebacher, J., Maugeri, M., Maheras, P., Nissen, K. M., Pavan, M., Pinto, J. G., Saaroni, H., Seubert, S., Toreti, A., Xoplaki, E., and Ziv, B.: Climate of the Mediterranean: Synoptic Patterns, Temperature, Precipitation, Winds, and Their Extremes, in: The Climate of the Mediterranean Region: from the Past to the Future, edited by: Lionello, P., Elsevier, Amsterdam, the Netherlands, 301-346, 2012.

Uppala, S. M., Kållberg, P. W., Simmons, A. J., Andrae, U., da Costa Bechtold, V., Fiorino, M., Gibson, J. K., Haseler, J., Hernandez, A., Kelly, G. A., Li, X., Onogi, K., Saarinen, S., Sokka, N., Allan, R. P., Andersson, E., Arpe, K., Balmaseda, M. A., Beljaars, A. C. M., van de Berg, L., Bidlot, J., Bormann, N., Caires, S., Chevallier, F., Dethof, A., Dragosavac, M., Fisher, M., Fuentes, M., Hagemann, S., Hólm, E., Hoskins, B. J., Isaksen, L., Janssen, P. A. E. M., Jenne, R., McNally, A. P., Mahfouf, J.-F., Morcrette, J.-J., Rayner, N. A., Saunders, R. W., Simon, P., Sterl, A., Trenberth, K. E., Untch, A., Vasiljevic, D., Viterbo, P., and Woollen, J.: The ERA-40 re-analysis, Q. J. Roy. Meteorol. Soc., 131, 2961-3012, doi:10.1256/qj.04.176, 2005.
Vich, M., Romero, R., and Brooks, H. E.: Ensemble prediction of Mediterranean high-impact events using potential vorticity perturbations, Part I: Comparison against the multiphysics approach, Atmos. Res., 102, 227-241, 2011a.

Vich, M., Romero, R., and Homar, V.: Ensemble prediction of Mediterranean high-impact events using potential vorticity perturbations, Part II: Adjoint-derived sensitivity zones, Atmos. Res., 102, 311-319, 2011 b.

Vich, M., Romero, R., Richard, E., Arbogast, P., and Maynard, K.: Perturbing the potential vorticity field in mesoscale forecasts of two Mediterranean heavy precipitation events, Tellus A, 64, 17224, doi:10.3402/tellusa.v64i0.17224, 2012.

WMO/PSPM: Report of the Informal Consultation on Mediterranean Cyclones, Sofia, 28 November-1 December 1983, PSPM Publication Series No. 3, WMO, Geneva, 1984.

WMO/PSPM: Report of the Steering Group Meeting on Mediterranean Cyclones Study Project, Palma, Mallorca, 25-29 November 1985, PSPM Report Series No. 20, WMO/TD No. 128, WMO, Geneva, 1986.

WMP/PSPM: Papers presented at the WMO Workshop on LimitedArea Fine Mesh Models for the Mediterranean Region, Erice, 17-20 November 1986, PSPM Report Series No. 26, WMO, Geneva, 1987.

WMO/PSPM: Report on the Third Session of the Steering Group of Mediterranean Cyclones Study Project, Barcelona, Spain, 17 March 1989, PSPM Report Series No. 31, WMO/TD No. 298, WMO, Geneva, 1989.

WMO/PSPM: Report of the Fourth Session of the Steering Group of Mediterranean Cyclones Study Project, Sofia, Bulgaria, 2528 March 1991, PSPM Report Series No. 33, WMO/TD No. 420, WMO, Geneva, 1991.

WMO/PWPR: Report of the Fifth Session of the Steering Group of Mediterranean Cyclones Study Project, Palma de Mallorca, Spain, 1-3 December 1993, PWPR Report Series Project No. 4, WMO/TD No. 600, WMO, Geneva, 1994.

Xoplaki, E., Luterbacher, J., Burkard, R., Patrikas, I., and Maheras, P.: Connection between the large-scale $500 \mathrm{hPa}$ geopotential height fields and precipitation over Greece during wintertime, Climate Res., 14, 129-146, 2000.

Ziv, B., Dayan, U., Kushnir, Y., Rothb, C., and Enzelb, Y.: Regional and global atmospheric patterns governing rainfall in the Southern Levant, Int. J. Climatol., 26, 55-73, 2006. 